REGEIVED

SEADS:-PC:

Sectoral Energy/Employment

Analysis and Data System
HOV - 81995

OSTI

\title{
Methodology, Capabilities, and an Example: Employment Impacts of the Climate Change Action Plan
}

J. M. Roop

D. M. Anderson

R. W. Schultz

September 1995

Prepared for

U.S. Department of Energy

under Contract DE-AC06-76RLO 1830

Pacific Northwest Laboratory

Richland, Washington 99352 


\section{DISCLAIMER}

This report was prepared as an account of work sponsored by an agency of the United States Government. Neither the United States Government nor any agency thereof, nor Battelle Memorial Institute, nor any of their employees, makes any warranty, expressed or implié, or assumes any legal liability or responsibility for the accuracy, completeness, or usefulness of any information, apparatus, product, or process disclosed, or represents that its use would not infringe privately owned rights. Reference herein to any specific commercial product, process, or service by trade namie, trademark $r$ manúfacturer, or ótherwise does not necessàrily constitute or imply its endorsement,' recommendation, or favoring by the United States Government or any agency thereof, or Battelle Memorial Institute. The views and opinions of authors expressed herein do not necessarily state or reflect those of the United States Government or any agency thereof.

\section{PACIFIC NORTHWEST LABORATORY} operated by

BATTELLE MEMORIAL INSTITUUTE for the

UNITED STATES DEPARTMENT OF ENERGY (1)... under Contract DE-AC06-76RLO 1830 
SEADS-PC:

Sectoral Energy/Employment

Analysis and Data System

\title{
Methodology, Capabilities, and an Example: Employment Impacts of the Climate Change Action Plan
}

\author{
J. M. Roop \\ D. M. Anderson \\ R. W. Schultz
}

September 1995

Prepared for

the U.S. Department of Energy

under Contract DE-AC06-76RLO 1830

Pacific Northwest Laboratory

Richland, Washington 99352 



\section{Executive Summary}

A software package, Sectoral Energy/Employment Analysis and Data System (SEADS-PC), that can translate policy changes into employment and energy impacts is described. The core data for this tool include input-output (I/O) tables for 1977, 1982, 1987, and 2005 in 1982 dollars, and I/O tables for 1987 and 1990 in 1987, dollars. For each of the $\mathrm{I} / \mathrm{O}$ tables there are corresponding final demand vectors and employment intensities. For all but the 2005 table there are energy intensities as well. The final demands and the intensities can be changed to reflect alternative policies. A final demand vector that reflects a specific policy, for example, can be created, based on an existing final demand vector. This vector can then be premultiplied by the appropriate $\mathrm{I} / \mathrm{O}$ table to yield industry output, which in turn can be multiplied by energy or employment intensities to yield employment or energy resulting from the policy scenario. These policy results can then be compared with a base case and the differences reported.

The report is in four sections. The first section is an introduction. The second section provides the accounting framework for the tool and describes the data provided. The third section serves as a user's guide to the software, describing the functionality of the program and what results can be expected. The fourth section uses the President's Climate Change Action Plan (CCAP) as an example policy for which employment impacts can be calculated.

The results of the CCAP exercise suggest that this program will result in about 60,000 new jobs (about 115 million additional hours of work) for the year 2000. In the year 2000, the CCAP final demands are greater than the base case final demands by $\$ 192.8$ million (1990 dollars). The additional jobs are created as a result of both the shifts among final demand categories and a slight increase in economic activity. 



\section{Acronymns}

BEA Bureau of Economic Analysis

BLS Bureau of Labor Statistics

CCAP Climate Change Action Plan

DRI Data Resources, Inc.

EIA Energy Information Administration

GDP Gross Domestic Product

I/O Input-output

MECS Manufacturing Energy Consumption Survey

OMB Office of Management and Budget

SEADS Sectoral Energy/Employment Analysis and Data System

SIC Standard Industrial Classification 



\section{Acknowledgments}

This document is a major revision of a program first developed by David B. Belzer in the mid-1980s; his contribution is gratefully acknowledged. The authors would also like to thank our U.S. Department of Energy sponsor, Peggy Podolak, Office of Economic Policy and Competition, (202) 586-6430, without whose support this work would not have been accomplished. Thanks also to Steve Shankle for his suggestions and comments, and to Susan Ennor for her editorial assistance.

Inquiries about SEADS-PC should be addressed to Joseph M. Roop, Pacific Northwest Laboratory, P.O. Box 999, MSIN: K8-17, Richland, WA 99352 (509) 37.2-4245. 



\section{Contents}

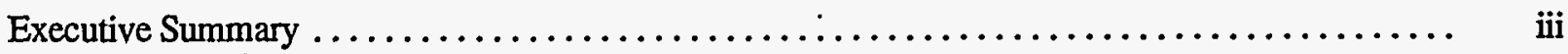

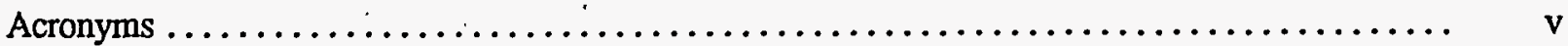

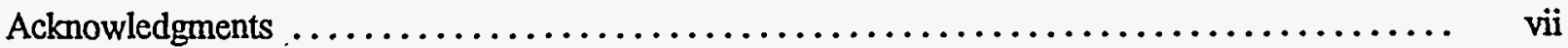

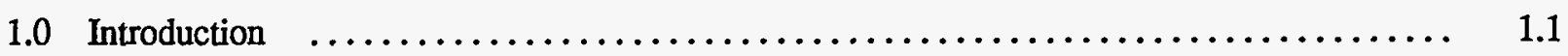

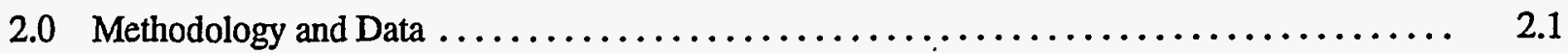

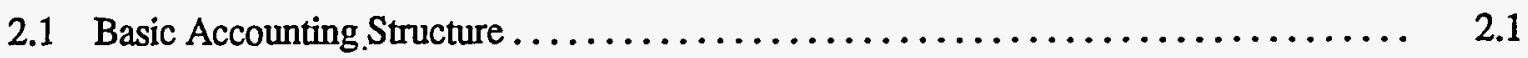

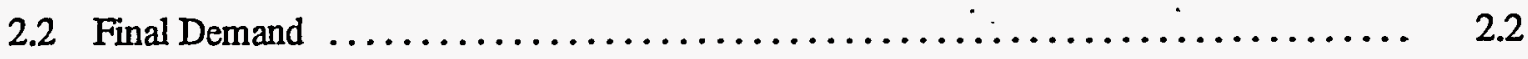

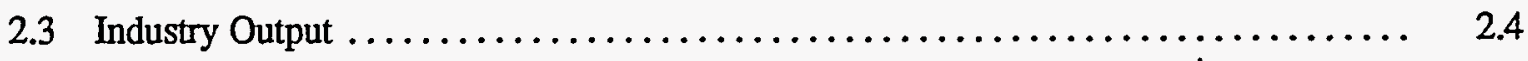

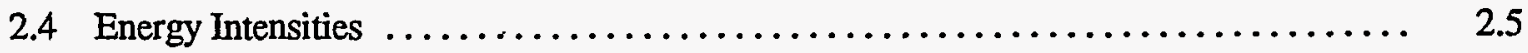

2.5 Relation of Equation Variables to SEADS Variables $\ldots \ldots \ldots \ldots \ldots \ldots \ldots \ldots \ldots$

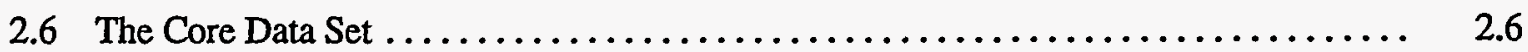

$2.7^{\circ}$ Industry Classifications $\ldots \ldots \ldots \ldots \ldots \ldots \ldots \ldots \ldots \ldots \ldots \ldots \ldots \ldots \ldots \ldots \ldots \ldots \ldots \ldots \ldots$

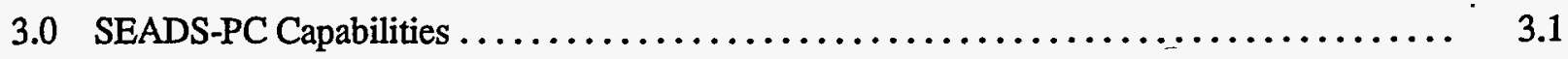

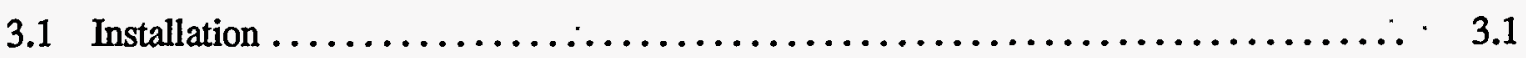

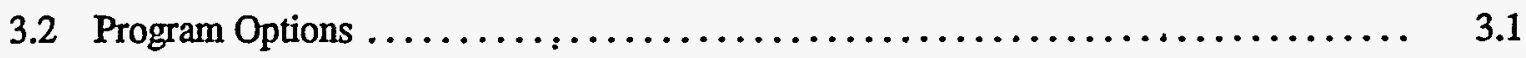

3.3 Computation of Labor and Energy Impacts $\ldots \ldots \ldots \ldots \ldots \ldots \ldots \ldots \ldots \ldots \ldots \ldots$

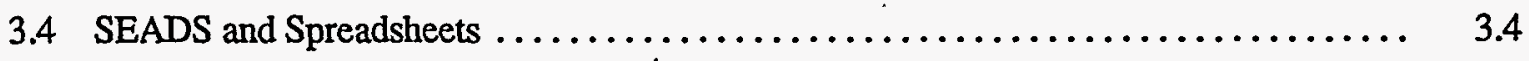

4.0 An Example Application: The Climate Change Action Plan $\ldots \ldots \ldots \ldots \ldots \ldots \ldots \ldots \ldots .4 .1$

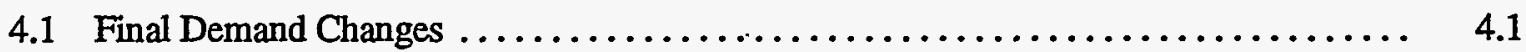

4.2 CCAP Labor Impacts: The Procedure $\ldots \ldots \ldots \ldots \ldots \ldots \ldots \ldots \ldots \ldots \ldots \ldots \ldots \ldots \ldots \ldots \ldots \ldots \ldots$

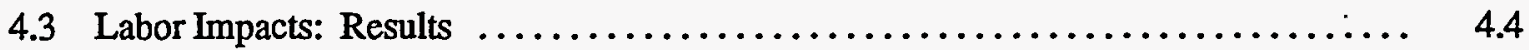

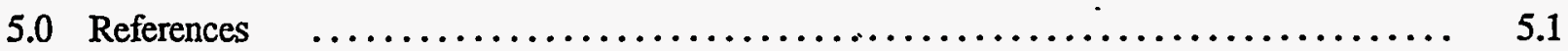

Appendix - Selected Detailed Tables and Results Files for the Example Application:

Employment Implications of the Climate Change Action Plan ................ A.1 
Figure

2.1 The Determination of Employment Using the SEADS-PC Approach

\section{Tables}

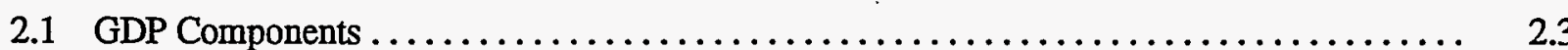

2.2 Correspondence Between Variables and Data Filès $\ldots \ldots \ldots \ldots \ldots \ldots \ldots \ldots \ldots \ldots \ldots$

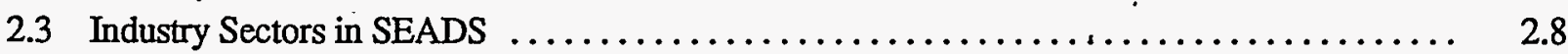

4.1 Summary Results File Showing Comparison Between Base Case and CCAP Case $\ldots \ldots \ldots \quad 4.1$

4.2 Base Case and CCAP Final Demands $\ldots \ldots \ldots \ldots \ldots \ldots \ldots \ldots \ldots \ldots \ldots \ldots \ldots \ldots \ldots \ldots \ldots \ldots \ldots \ldots$

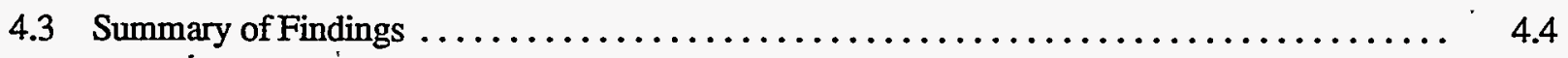




\subsection{Introduction}

This guide was written by staff of the Pacific Northwest Laboratory ${ }^{(a)}$ for users of the SEADS-PC (Sectoral Energy/Employment Analysis and Data System) for IBM-compatible computers using Windows. SEADS is designed to show the employment and energy implications of changing the industrial structure and patterns of final demands for goods within the U.S. economy.

This version of SEADS-PC is a Windows-based program, written in VisualBasic with extensive documentation provided through help documents. This user's guide provides instructions for preparing various scenarios with the system and walks the user through a typical exercise of running a scenario and preparing tables and spreadsheets. The example used to demonstrate the analytical tool is a comparison of a Climate Change Action Plan scenario with a base case forecast for the year 2000.

SEADS contains core data for analysis for four base years: $1977,1982,1987$, and 1990 . The core data include a vector of final demands, an input-output table, energy intensities, and labor intensities. A set of multipliers that convert national labor and hours data from the national to the state level is also available and can be applied to all core data sets. Input-output, final demand, and employment (i.e., labor intensity) data are also available for the Bureau of Labor Statistics (BLS) forecast year 2005 (BLS 1993). Forecasts of Gross Domestic Product (derived from the U.S. Department of Energy's subscription to Data Resources, Inc. forecasts) between 1995 and 2010 are provided at five-year intervals, with the capability of bridging from these forecasts to a vector of final demands that can generate outputs for analysis. The example analysis is done using both the current (i.e., 1990) industry structure and the industry structure represented by the BLS 2005 input-output table.

This report is organized into three additional sections. The next section provides the accounting framework for the analytical tool and describes the data that constitute the core data set provided with the model. The third section describes the capabilities of SEADS and indicates how the tool can be used to examine a variety of questions that bear on energy policy. The final section demonstrates the analytical power of the tool by applying it to the Climate Change Action Plan.

(a) The Pacific Northwest Laboratory is operated by the Battelle Memorial Institute for the U.S. Department of Energy under Contract DE-AC06-76 RLO 1830. 



\subsection{Methodology and Data}

\subsection{Basic Accounting Structure}

The basic input-output $(\mathrm{I} / \mathrm{O})$ accounting structure employed in SEADS, along with the employment and energy calculations, are shown in Figure 2.1. The box at the top of the figure is optional. The Data Resources, Inc. (DRI) forecasts (the example is for 1995) are converted through a bridge matrix to a vector of final demands. Alternatively, the user could start with one of the provided final demand vectors. The sum of all final demands is the Gross Domestic Product (GDP). The selected or constructed final demands are premultiplied by the total requirements matrix (labeled "Input-Output Table") to yield industry output for each of the 85 industries. This total output for each industry is shown as the box labeled "Industry Output." From a cost perspective total output for each industry must equal the cost of purchased commodities plus value added. Value added consists of payments to primary factors - labor compensation, capital or profit-type income, and indirect business taxes. These outputs are not available separately, but are intermediate in the calculation of jobs and hours or energy use.

Employment intensity is shown in the box labeled, "Jobs and Hours Intensities" beneath the output box. These intensities were calculated by dividing jobs or hours for each of the 85 industries by output. Thus these intensities represent the jobs or hours per dollar of output for each of the industries for which output is calculated.

Energy intensity is defined in terms of Btu/per dollar of output, analogous to employment intensities. These intensities are also shown in the figure as an alternative path. Like employment, there is no single intensity for each industry; rather, in SEADS intensities are defined for four fuel types-coal, oil, natural gas, and electricity. Energy use, is computed as the product of output times intensity, on an industry-by-industry basis for each fuel. Similarly, employment (i.e., jobs and hours) is computed as the product of output times employment intensity, on an industry-by-industry basis, and this is shown in the figure. SEADS also provides an option to define a subregion of the United States for which employment (but not energy) impacts can be determined. These regional impacts are calculated by sharing the nation impacts down to the state (or regional) level. This is shown as an option in Figure 2.1.

Figure 2.1 helps to provide some perspective of the relationship between the composition of GDP and employment or energy use in the economy. One of the key capabilities in SEADS is the ability to calculate employment based on an arbitrary set of final demands. By itself, Figure 2.1 does not spell out how this procedure is performed. For this, a more detailed explanation, in terms of the basic matrix algebra underlying . the I-O method employed in SEADS, is provided below. 


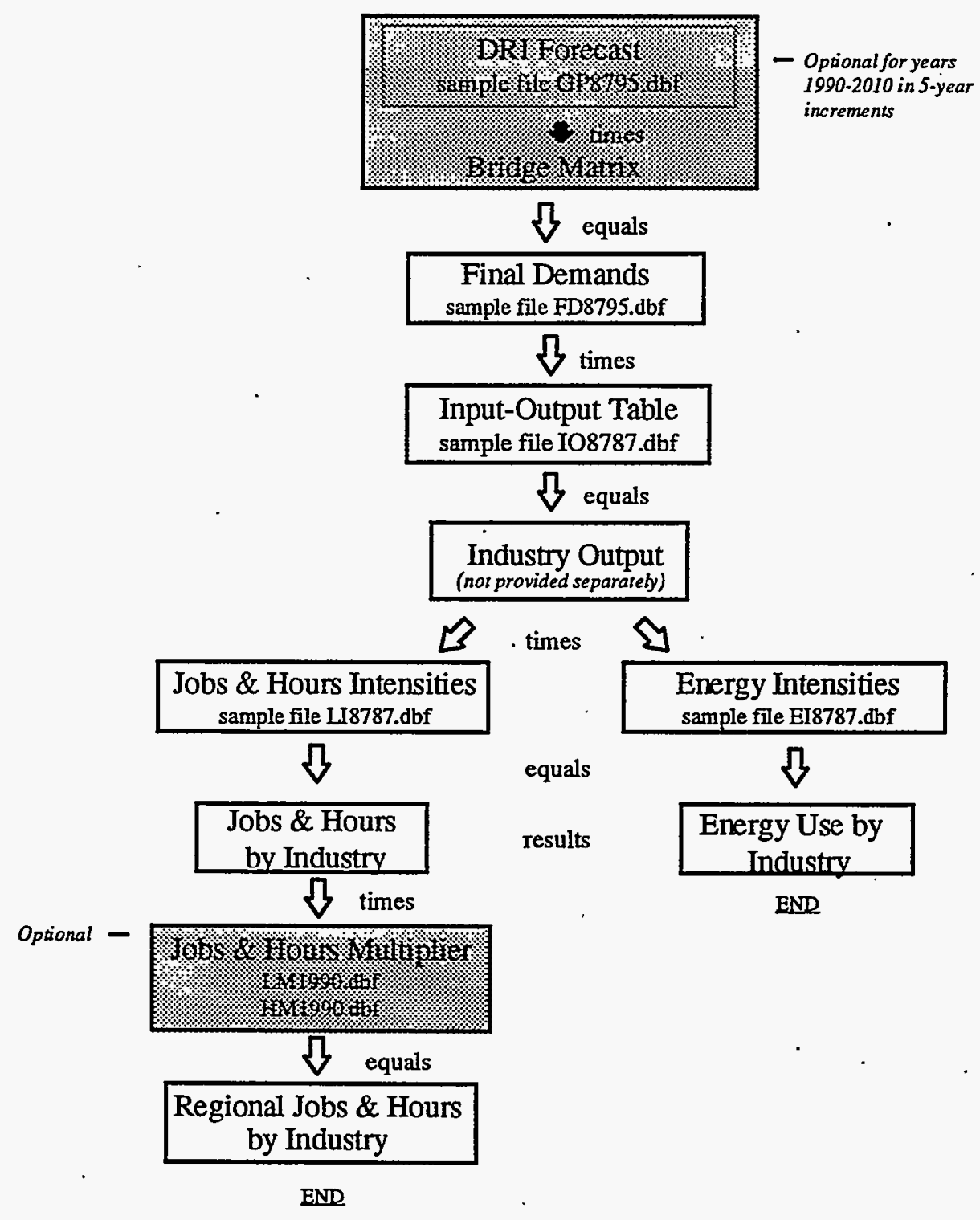

Figure 2.1. The Determination of Employment Using the SEADS-PC Approach

\subsection{Final Demand}

We begin first with the determination of final demands by commodity. Let $F$ be a column vector of total final demand by commodity. In SEADS we follow the Bureau of Economic Analysis (BEA) convention of reporting 85 commodities and industries, as listed in Section 2.7 (BEA 1991). In terms of Figure 2.1, Final Demands is a $85 \times 1$ vector that is the row sums of the various components, including personal consumption expenditures, business investment components, and other final demand components. In SEADS a forecast set of GDP components can be converted to this final demand vector and used to generate employment impacts. There are 29 of these final forecast demand categories, as shown in Table 2.1. 
Table 2.1. GDP Components

\begin{tabular}{|c|c|}
\hline No. & Sector \\
\hline 1 & C-Motor Vehicles \\
\hline 2 & C-Fumiture \& Appliances \\
\hline 3 & C-Other Durables \\
\hline 4 & C-Food \& Beverages \\
\hline 5 & C-Clothing \& Shoes \\
\hline 6 & C-Gasoline \& Oil \\
\hline 7 & C-Fuel Oil \& Coal \\
\hline 8 & C-Other Nondurables \\
\hline 9 & C-Housing Services \\
\hline 10 & C-Household Electric Services \\
\hline 11 & C-Household Natural Gas Services \\
\hline 12 & C-Other Household Services \\
\hline 13 & C-Transportation Services \\
\hline 14 . & C-Medical Services \\
\hline 15 & C-Other Services \\
\hline 16 & I-Nonresidential Equipment \\
\hline 17 & I-Nonresidential Structures \\
\hline 18 & I-Residential Structures \\
\hline 19 & I-Residential Equipment \\
\hline 20 & I-Manufacturing Inventory Change \\
\hline 21 & I-Retail Trade Inventory Change \\
\hline 22 & I-Wholesale Trade Inventory Change \\
\hline 23 & I-Other Nonfarm Inventory Change \\
\hline 24 & I-Farm Inventory Change \\
\hline 25 & Exports \\
\hline 26 & Imports \\
\hline 27 & G-National Defense \\
\hline 28 & G-Federal Nondefense \\
\hline 29 & G-State \& Local Government \\
\hline \multicolumn{2}{|c|}{$\begin{array}{l}\text { C: Consumption } \\
\text { I: Investment } \\
\text { G: Government }\end{array}$} \\
\hline
\end{tabular}


For an I/O application, there must be an industrial distribution of final demand categories with entries for each of the 85 rows of the final demand array in Figure 2.1. Thus, to convert from these 29 forecast categories to the 85 industries, a "bridge" is used. For example, for category 16, Nonresidential Equipment (Producers Durable Equipment), there would be non-zero row entries corresponding to a number of producing sectors, including machine tools, motor vehicles, other transportation equipment, etc. Let matrix $\mathrm{H}$ represent this distribution after normalization to a per-dollar-of-final-demand basis. That is, an element of $H$, $h_{i j}$, represents the amount of commodity i sold per dollar's worth of final demand category $j$. Because this distribution is fairly stable over time, one can translate a given vector of GDP final demand categories into a vector of commodity demands via the matrix expression.

$$
\mathrm{F}=\mathrm{HG}
$$

The dimension of $\mathrm{H}$ in SEADS is $85 \times 29$. $\mathrm{H}$ is commonly referred to as a bridge matrix, because it is used to bridge between the GDP category and commodity levels of final demand.

\subsection{Industry Output}

The next step is to compute the levels of output that would be required to satisfy the final demands by commodity $(\mathrm{F})$. In standard $\mathrm{I} / \mathrm{O}$ analysis, the fundamental identity is

$$
\mathrm{X}_{\mathrm{c}}=\mathrm{AX}_{\mathrm{c}}+\mathrm{F}
$$

where: $A=$ an nxn matrix of direct requirements coefficients,

$\mathrm{X}_{\mathrm{c}}=$ an $\mathrm{nx} 1$ vector of outputs, and

$\mathrm{F}=$ an $\mathrm{nxl}$ vector of final demands.

A is defined on a commodity-by-commodity basis, where $a_{i j}$ represents the amount of commodity $i$ required in the production of a dollar's worth of commodity $j$. From Equation (2.2), the solution for $F$ is obtained by:

$$
X_{c}=(I-A)^{-1} F
$$

$(\mathrm{I}-\mathrm{A})^{-1}$ is commonly known as the Leontief inverse.

This simple solution to Equation (2.2) is based on the existence of a commodity-to-commodity direct requirements table, A. Such a table is not published as part of the official I/O accounts for the United States. Rather, the U.S. Department of Commerce in the 1972 and subsequent input-output studies has released two separate tables, a "use" table and "make" table. The use table shows the value of each commodity used by each industry. The make table, on the other hand, shows the value of each commodity produced by each industry. 
By using the use and make matrices, some organizations have generated estimates of commodity-bycommodity tables for the 1972 and 1977 U.S. input- output studies. SEADS, however, has followed an alternative approach used by the U.S. Department of Commerce (BEA 1994). This approach employs what is termed an industry-technology assumption, which assumes that industries employ commodities in fixed proportion to their total industry (rather than commodity) output. To determine industry output, a second assumption must also be made, namely that the market shares by each industry in the production of a specific commodity remain constant.

The derivation of the solution for industry output using these assumptions is somewhat tedious and will not be given here. The final result is:

$$
\mathrm{X}=\mathrm{D}(\mathrm{I}-\mathrm{BD})^{-1} \mathrm{~F}
$$

where: $I=$ the identity matrix

$\mathrm{X}=\mathrm{a}$ vector of industry outputs

$\mathrm{F}=$ a vector of final demands by commodity

$\mathrm{D}=$ an industry-by-commodity matrix in which entries in each column show for a given commodity the proportion of total output of that commodity produced in each industry. $\mathrm{D}$ is referred to as the market share matrix, and is constructed from the Make matrix.

$\mathrm{B}=\mathrm{a}$ commodity-by-industry matrix in which entries in each column show the amount of a commodity used by an industry per dollar of output of that industry. This is constructed from the Use matrix.

In the development of this version of SEADS, the matrix $D(I-B D)^{-1}$ for all core years except 1982 was computed from the use and make matrices provided by the Long-Term Growth Project of the BLS. For 1982, the official benchmark table was used. A benchmark table for 1987 is also provided. This total requirements matrix is represented by the box labeled "Input-Output Table" in Figure 2.1.

The core data include four BLS total requirements matrices in 1982 dollars and two BLS matrices in 1987 dollars. The BLS tables in 1987 dollars were developed using the 1982 Standard Industrial Classification (SIC) definitions, which were significantly revised with the publication of the 1987 benchmark I/O table. Constant dollar tables are needed for comparison through time, so we have provided the BLS tables. The benchmark 1987 table is also provided, although this table is not comparable with the other tables because of the SIC changes.

\subsection{Energy Intensities}

The computation of energy intensities was straightforward. Energy-use data by industry and fuel were taken from the National Energy Accounts (NEA; Jack Faucett Associates 1989), which contain data for the period from 1958 to 1985 . Fuel types were aggregated to four major categories: coal, natural gas, oil and electricity. The industry data were converted to the BEA industries using a concordance based on SIC codes (Office Management Budget [OMB] 1987). Data for 1987 and 1990 were constructed to match with the Manufacturing Energy Consumption Survey (MECS) data for manufacturing for 1988 (Energy Information 
Administration [EIA] 1991) and 1991 (EIA 1994), and for other industries based on Annual Survey (Bureau of the Census 1992) and Census (Bureau of the Census 1990) data.

To generate historical energy intensities, historical output data were taken from the Office of Economic Growth in the BLS. After aggregation to the BEA basis, the outputs were scaled to match the industry outputs from the core year $I / O$ table. Intensities for each fuel type were then computed as simply the energy use by industry sector divided by the industry output.

SEADS-PC saves the results of calculating the projected or simulated energy use by industry. In matrix notation the energy-use matrix is calculated as:

$$
\mathrm{E}=\mathrm{e} . \mathrm{X}
$$

where: $E=$ energy use, with dimension: industry $x$ fuel type

$e=$ a matrix of energy intensities (for a specific year) of dimension fuel type $x$ industry

.$=$ a dot product operation, i.e., $\mathrm{X}$ is diagonalized before matrix multiplication.

Using the matrix E, energy consumption for any desired aggregation of industries can be easily calculated. A similar set of intensities for jobs and hours allows for the computation of labor use based on generated industry output.

\subsection{Relation of Equation Variables to SEADS Variables}

To go from the 29 final demand categories $(G)$ to the matrix of energy use/employment by industry the complete procedure in SEADS requires the calculation of $F$ (Equation 1), then the following matrix expression:

$$
E=e .\left[D(I-B D)^{-1}\right] F
$$

In the instructions that follow in the next section, the user will generally select a set of these various components in Equation (2.6) to perform a wide variety of analyses. In addition to selecting these files, the user may wish to edit any of the various arrays for which editing is allowed to tailor the analysis to some special purpose applications. For employment impacts rather than energy impacts, there is a third set of variables: an employment multiplier that allows the translation from national employment impacts to state-level impacts. To facilitate these applications, the SEADS variables corresponding to these components are listed in Table 2.2 (a single bridge matrix is provided by the program-it is contained in a file called BRIDGE.DBF).

\subsection{The Core Data Set}

The data that have been constructed for SEADS include I/O tables for a variety of years, energy intensities for most of the years, labor intensities for these years, and final demands for the core set of 
Table 2.2. Correspondence Between Variables and Data Files

\begin{tabular}{||l|l|l||}
\hline \hline Matrix/Vector & \multicolumn{1}{|c|}{ SEADS } & \multicolumn{1}{|c|}{ Description } \\
\hline G & gp1987.dbf & GDP Components, 1987 \\
\hline F & fd1987.dbf & Aggregate Final Demand, 1987 \\
\hline D(I-BD)-1 & io1987.dbf & Input-Output Table for 1987 \\
\hline e & ei1987.dbf & Energy Intensity for 1987 \\
\hline 1 & li1987.dbf & Labor Intensities for 1987 \\
\hline Im & Im1990.dbf & Jobs Multiplier \\
\hline hm & hm1990.dbf & Hours Multiplier \\
\hline
\end{tabular}

years. There are seven I/O tables: for 1977, 1982, 1987 and 2005, all in 1982 constant dollars (naming convention: “io1987.dbf"); and for 1987 and 1990 in 1987 dollars ("io8787.dbf" and "io8790.dbf") based on the 1982 SIC definitions; and the benchmark 1987 table ("io87bm.dbf"). There are also seven final demand vectors with similar naming conventions (i.e., “fd1977.dbf” for \$1982; “fd8790.dbf" for \$1987, and "fd87bm.dbf" for the benchmark final demands) and seven labor intensities (prefix "li") similarly named: There are only six energy intensity files (prefix "ei"), matched to all except the 2005 data, for which there are no adequate forecasts. There is only one file for each of the labor and hours multipliers (prefixes " $\mathrm{lm}$ " and " $\mathrm{hm}$ ") for 1990. These files share the national totals to the state level and are constructed for only one year. A bridge matrix is also provided, "bridge.dbf" based on the 1987 final demands, that maps from the gp files to the fd files. Experiments with the 1977 and 1987 data suggest that this bridge does not change significantly over time.

\subsection{Industry Classification}

The industry classification used in this version of SEADS-PC is one that is used by the BEA, U.S. Department of Commerce, and it might be termed the standard I/O (85-Sector) classification. This classification is shown in Table 2.3, and is based on the 1982 SIC (BEA 1991). The sector classification changed substantially in 1987; we have retained the 1982 industry definitions. 
Table 2.3. Industry Sectors in SEADS ${ }^{(a)}$

\begin{tabular}{|c|c|}
\hline NoJ Industry & \\
\hline 1 Livestock and livestock products & 44 Farm and garden mach. \\
\hline 2 Other agri. products & 45 Construction and mining mach. \\
\hline 3 Forestry and fishery products & 46 Materials handling mach. and equip. \\
\hline 4 Agri., forestry, and fishery serv. & 47 Metalworking mach. and equip. \\
\hline 5 Iron and ferroalloy ore mining & 48 Special industry mach. and equip. \\
\hline 6 Nonferrous metal ore mining & 49 General industrial mach. and equip. \\
\hline 7 Coal mining & 50 Misc. mach. except elec. \\
\hline 8 Crude petroleum and natural gas & 51 Office, computing, and accounting equip. \\
\hline 9 Stone and clay mining and quarrying & 52 Serv. industry machines \\
\hline 10 Chem \& fertilizer mineral mining & 53 Elec. industrial equip. and apparatus \\
\hline 11 New constnuction & 54 Household appliances \\
\hline 12 Maintenance and repair construction & 55 Elec. lighting and wiring equip. \\
\hline 13 Ordinance and accessories & 56 Radio, TV, and communications equjp. \\
\hline 14 Food and kindred products & 57 Elec. components and accessories \\
\hline 15 Tobacco & 58 Misc. elec. mach. and supplies \\
\hline 16 Broad and narrow fabrics & 59 Motor vehicles and equip. \\
\hline 17 Misc. textiles and flooring & 60 Aircraft and parts \\
\hline 18 Apparel & 61 Other transportation equip. \\
\hline 19 Misc. fabricated textiles & 62 Scientific and controlling instr. \\
\hline 20 Lumber and wood products & 63 Optical, ophthalmic, and photo equip. \\
\hline 21 Wood containers & 64 Misc. mfg. \\
\hline 22 Household funniture & 65 Transportation and warehousing \\
\hline 23 Other fumiture and fixtures & 66 Communications, except radio and TV \\
\hline 24 Paper and allied products & 67 Radio and TV broadcasting \\
\hline 25 Paperboard containers and boxes & 68 Elec., gas, water, and sanitary serv. \\
\hline 26Printing and publishing & 69 Trade \\
\hline 27 Chemicals and selècted products & 70 Finance and insurance serv. \\
\hline 28 Plastics and synthetic materials & 71 Real estate \\
\hline 29 Drugs, cleaning and toilet prep. & 72 Hotel and lodging serv. \\
\hline 30 Paints and allied products & 73 Business serv. \\
\hline 31 Petroleum refining industries & 74 Eating and drinking places \\
\hline 32 Rubber and misc. plastics & 75 Automobile repair serv. \\
\hline 33 Leather tanning and finishing & 76 Amusements \\
\hline 34 Footwear and other leather products & 77 Health, education, and social serv. \\
\hline 35 Glass and glass products & 78 Federal govemment enterprise \\
\hline 36 Stone and clay products & 79 State and local govemment enterprise \\
\hline 37 Primary iron and steel mfg. & 80 Noncomparable imports \\
\hline 38 Primary nonferrous metal mfg. & 81 Scrap \\
\hline 39 Metal containers & 82 Govemment industry \\
\hline 40 Fabricated structural metal products & 83 Rest of the world industry \\
\hline 41 Screw machine prod and stampings & 84 Household indụstry \\
\hline 42 Other fabricated metal products & 85 Inventory valuation adjustment \\
\hline 43 Engines and turbines & \\
\hline $\begin{array}{l}\text { (a) agri. = agricultural; elec. = electric } \\
\text { machinery; mfg. = manufacturing; } \\
\text { services. }\end{array}$ & $\begin{array}{l}\text { equipment; instr. }=\text { instruments; mach. }= \\
\text { scellaneous; prep. = preparations; serv. = }\end{array}$ \\
\hline
\end{tabular}




\subsection{SEADS-PC Capabilities}

Installation of SEADS-PC makes various program options and computational capabilities available to you, as described in the following sections.

\subsection{Installation}

SEADS-PC is installed by following the instruction in the READ.ME file that comes with the SEADS diskettes. The installation kit includes two diskettes. The first of these is put into the diskette drive (A: $\downarrow$ for example), and the Run option is selected under the File selection under Program Manager. The Run command would be A:SETUP. The data files are loaded by copying all of the core files from the subdirectory A:DBF to a similar subdirectory under the SEADS directory.

\subsection{Program Options}

SEADS-PC includes the use of various screens and options that are described here.

SEADS Screen. Once installed, the program is invoked by double-clicking on the SEADS icon. The opening window of SEADS has six options on the options bar at the top of the screen, but under the title bar. The Select Files options allows you to load files for each of the bulleted items show in the middle of the screen. The Edit File option allows you to edit selected files. The New and Save As... options allow you to copy and rename existing files to modify them. The Set Defaults option establishes a set of selected files as the default files to load whenever SEADS is invoked; and the Exit option returns you to the Windows Program Manager.

The major part of the opening screen is a matrix with three column headings and three major row headings. The columns are labeled File Type, Selected Files/Options, and Computational Options. The headings that define the major rows are labeled Macro Specification, Energy Specifications, and Labor Specifications. Under the File Type column and in the Macro Specification row, three files types are identified-GDP, Final Demand, and I/O Table. Once a set of default files has been identified, these are loaded automatically and will be identified under the second column. If these are blank, the user should invoke Select Files to identify a set of files to work with. There are two function buttons under the first column labeled FUEL TYPE and LABOR REGION. The first allows you to choose the set of fuels you wish to include in the analysis; the second allows you to specify a region or state to examine for employment impacts. The second column will identify what options are chosen using these buttons; the defaults are all fuel types and the entire Unites States.

Under the third column are three buttons that perform the calculations for the SEADS tool. The first of these, labeled GENERATE FINAL DEMAND performs the calculation shown in Equation 2.1. Using a bridge matrix, it maps from the 29 components of GDP to the 85-component final demand vector. When this option is invoked, SEADS will ask for a file name for the newly created file. The second button, labeled COMPUTE 
ENERGY USE, performs the calculation of Equation (2.5), where e is energy intensity. Progress during these calculations is indicated on a overlay screen. The third button is labeled COMPUTE LABOR USE, and this button calculates Equation (2.5) using labor and hours intensities rather than energy intensities. Further, if a region or a state has been selected, the results for the United States will be shared down to the state or region based on state level employment information by industry. If the default is used, there is no need for this sharing down to occur. This computation also reports progress with an indicator.

If a region or state is selected, the mouse is clicked on the LABOR REGION button and a map of the United States (sans Hawaii, which will be included in the next release) appears. Buttons on the right-hand side of the map provide six pre-defined regions: WESTERN, EASTERN, CENTRAL, GREAT LAKES, COASTAL, and ENTIRE U.S. Below these regions are two additional buttons, a CLEAR ALL button that clears all current specified states/regions, and an $\mathbf{O K}$ button that returns you to the main program. When you first enter this map, all states are displayed in yellow, indicating that the default, Entire U.S., is currently invoked. By clicking on a state, that state changes color, indicating that a new region has been defined, consisting of all states except the one on which you clicked. To define a particular region, first hit CLEAR ALL, then click on the states of interest. When these are colored and the remainder of the map is not, you have specified a Custom Region, which will be indicated in the box under the second column headings when you return to the main menu. If you wish to delete a state from a Custom Region, just click on it a second time-and it will be removed from that user-defined region.

Select Files Screen. When you select this option, a File Selector screen appears that shows the files currently selected, the directory and files within which you are operating (usually C:SEADSDBF(*.*) and three buttons: SELECT, CLEAR, and RETURN. To the left of the selected files is a column of file types, with bullet-like buttons on the extreme left. By selecting a bullet, a black dot will fill the bullet, indicating that you are doing something with this type of file. For example, if you select Final Demand, you could clear the current file or you could identify a file from those shown in the File Names section to use for this exercise. Final demand files are identified by the fd prefix, then a year, then the extension dbf: So if you identify "fd1987.dbf" from the file names, then click on the SELECT button, that file will appear in the Selected Files area for that file type. Because each file type has a predefined form, you will receive an error message if you select an incorrect file type. When all necessary files for your analysis are selected, click on the RETURN button and the program reverts to the SEADS main menu.

Edit File Screen. When you invoke the Edit File option from the main menu, the editor will load the file currently identified by the highlighted button to the left of the selected file. If you wish to edit the final demand vector that you create from a GDP forecast, invoke this option with the highlighted button on the created file, and the next screen you see will be a standard Windows edit screen with the operating cell where changes are made at the top of the editor. The remainder of the screen is filled with three columns: the first column contains the number of the sector; the second contains the title for this sector, and the third contains the values currently in the aggregate final demand vector. If you want to change the current value for row 35 , Glass and Glass Products, simply 1) click on that cell, which loads row 35 into the editor, 2) click on the edit cell and make changes in the edit box, and 3) hit Enter. When all editing is complete, you can save the file 
under its current name or a different name (the Save or Save As... options): The Cancel option restores the file to its original state. The Units option tells the user the units for the current numbers. Finally, the Return option returns you to the main menu. If you have not saved the file, your changes will not be saved.

New and Save As... Screens. Both of these options invoke the New File Name menu screen, which either allows you to substitute a new file for the current file identified with the highlighted bullet or save that file under a different name.

Set Defaults Screen. Once a set of files has been selected, using this option will identify this set of files as the one you want to load the next time you enter SEADS.

Exit Option. This option returns computer control to the Windows Program Manager.

\subsection{Computation of Labor and Energy Impacts}

When either the CoMPUTE ENERGY USE or the COMPUTE LABOR USE buttons are invoked at the main menu, Equation (2.5) is computed with the files that were identified. When the calculation is complete, the results are shown on the next screen. These results can be saved under a new name, printed, or compared with a prior run; the units used can be shown, a summary table of the results can be shown; or you can return to the main menu. These are in the options bar at the top of the page and their functions are described here.

Save As... Option. This invokes the New Name screen and allows you to save results under a different name, and it is identical to the same option under the main menu. When a file is saved, it is saved under a *.dbf format, with a corresponding file with $\mathrm{a}$ *.dbs designation. This latter file contains all relevant information about what files were used to produce this result and the date and time of the run.

Print Option. This option allows you to print either to a printer (the Windows default) or to a file. If the Print-to-File option is selected, the results will be printed to a text file that a can then be accessed by a word processing package. When you print to a file, the relevant data contained in the *.dbs file will be printed along with the results.

Compare Option. With this option, you can compare the current results with results obtained from a prior run. Just identify the previously named file and these two files will be compared. The Results screen is similar to the Energy (Employment) Results screen, except that now both the results and the differences are shown on the screen. You can scroll down to the bottom of the results to see the total impact. The Save As... option here is the same as it is on the Results screen.

Summary Option. This option can be invoked from either the Results screen or the Compare screen. The Results Summary would show energy use by fuel type for the entire economy and energy use by major sectors-Agriculture, Mining, Construction, Manufacturing, Services, Other, and Total-for each fuel. From the comparison option, these headings would show both scenarios and the difference between the two. When the Summary Print-to-File option is employed, these final results, along with the two scenario descriptions, are all printed to the file name that you identify. 
Units and Return Options The Units option is the same as it is in the Edit File menu. The Return option returns to the SEADS main menu.

\subsection{SEADS and Spreadsheets}

SEADS is designed to be used with any of the major spreadsheet programs currently available under Windows-Quattro Pro, Lotus 1-2-3, or Excel. Any of these packages will read and write *.dbf files, making it easy to structure special analytical files. Most users will find it more convenient to structure analysis files in a spreadsheet environment than to use the editor provided in SEADS. Because all files are stored in dBase format, it is important that revisions to existing files preserve the structure of the original dBase files. The most efficient way to ensure this is to copy the appropriate set of numbers from a working spreadsheet, close the spreadsheet file, then paste these numbers into a template for the appropriate file. The naming convention for a template is ??_FORM.DBF, where ?? will be FD, EI, or any other label that is allowed. Be sure that when you save this file you do not overwrite the template. The template files are stored in the C:SEADS directory. An example of how this is done is provided in the next section. In addition, if the comparison of results is to be shown, it is necessary to read in the results.dbf files and take the differences between these two files to show as a comparison file. 


\subsection{An Example Application: The Climate Change Action Plan}

This section describes how to perform an analysis with the SEADS-PC system, using as an example the President's proposed Climate Change Action Plan (CCAP). More detailed tables and results files are in the Appendix.

\subsection{Final.Demand Changes}

For this analysis, two final demand vectors were provided: one a base case for the year 2000 , the other the same final demands under the CCAP. Table 4.1 shows the summary results file saved during a comparison between the base case and CCAP case using the I/O table for 2005 and employment intensities for 2005.

Table 4.1. Summary Results File Showing Comparison Between Base Case and CCAP Case (Using I/O table and Employment Intensities for 2005)

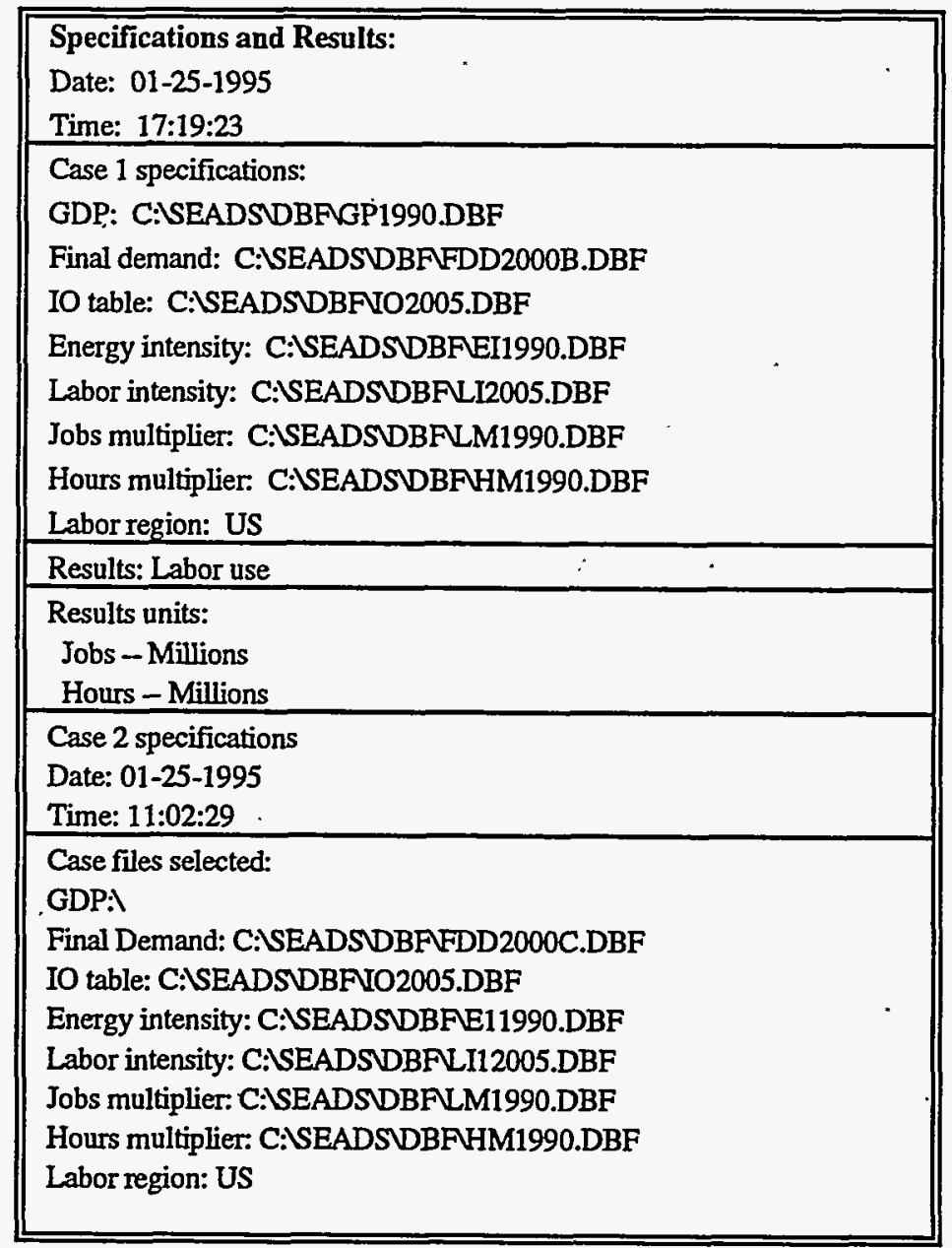


The difference between these two scenarios (in 1990 dollars) is shown in Table 4.2. Overall there is very little difference between these final demand vectors, with the difference for all industries adding up to only $\$ 192.8$ million, with CCAP expenditures slightly higher by that amount. While this sum is small, there are some large differences between the two scenarios for some categories of final demand. The largest of these are for new construction (larger under CCAP by $\$ 2.3$ billion), petroleum refining (lower under CCAP by nearly $\$ 2.8$ billion), and electric and gas utility sales (lower under CCAP by $\$ 3.8$ billion). The decline in energy sales through these two major sectors are compensated for by smaller changes in many other industries.

These final demand changes are both in 1990 dollars, so the first task was to convert these to 1982 dollars (the constant dollar value for the $2005 \mathrm{I} / \mathrm{O}$ table). To convert the final demand vectors to 1982 dollars the output deflators were first converted to final demand deflators by postmultiplying the output deflators by the inverse of the total requirements matrix, as given in Equation 2.4. ${ }^{\text {(a) }}$ This vector of final demand deflators was then multiplied, element by element, by both the CCAP and the 2000 base final demand vectors. Then both of these deflated final demand vectors were run through SEADS using both the 1990 and the $2005 \mathrm{I} / O$ tables to conduct the analysis. The deflation procedure reduces the value of the final demand vector from $\$ 6.25$ trillion to almost $\$ 5$ trillion and reduces the CCAP expenditures so that they are now smaller than the base case by $\$ 886$ million. These differences are shown in Appendix A, Table A.5.

\subsection{CCAP Labor Impacts: The Procedure}

Eight runs were performed to assess the employment impact of the President's CCAP. SEADS was employed for both the base case and the CCAP final demands using two different sets of I/O tables (1990 and 2005) and two sets of labor intensities (again 1990 and 2005). The results were saved as *.dbf files and the comparisons were saved as print files that contain information about the runs, an example of which is shown in Table 4.1. Table 4.3 was constructed by loading the results files into Lotus 1-2-3, copying the information, closing the file, then pasting the data to a standard *.wk3 file. (This procedure is necessary in Lotus, because the template for an *.dbf file will override the calculations and only part of the data will be saved, even if the file is saved using the Save As... option.) Results from each of the *.dbf files for the eight runs was likewise copied to a spreadsheet, then organized to be written to a disk file for loading into WordPerfect. All of the files included in this analysis are included with the installation kit, so that any or all of the results can be duplicated.

(a) The same relationship holds between the output deflator and the final demand deflator as holds for output and final demand in Equation 2.4. Because BLS supplies the output deflators $(1982=100)$ for each year from 1958 to 1990 , it is a simple matter to take the output deflator for 1990 , substitute the deflator series for $\mathrm{X}$ in Equation 2.4, then solve the equation for the final demand deflators by premultiplying each side of the equation by the inverse of the total requirements matrix. The result is the final demand deflator that was applied to the CCAP and base case final demands. 
Table 4.2. Base Case and CCAP Final Demands

\begin{tabular}{|c|c|c|c|}
\hline No./Industry Description & Base 2000 & CCAP 2000 & Difference \\
\hline 1-6 Six Industries & 45562.9 & 45579.6 & -16.7 \\
\hline 7 Coal mining & 5363.7 & 5316.9 & 46.8 \\
\hline 8-10 Three Industries & -41440.6 & -41440.1 & -0.5 \\
\hline 11 New construction & 512510.1 & 514858.5 & -2348.4 \\
\hline 12 Maintenance and repair construction & 60522.3 & 60633.2 & -110.9 \\
\hline 13 Ordinance and accessories & 23217.8 & 23171.6 & 46.2 \\
\hline 14 Food and kindred products & 249208.2 & 249279.0 & -70.8 \\
\hline 15-21 Seven Industries & 94242.9 & 94307.9 & -65.0 \\
\hline 22 Household fumiture & 21587.7 & 21693.1 & -105.4 \\
\hline 23 Other fumiture and fixtures & 24570.7 & 24689.3 & -118.6 \\
\hline 24 Paper and allied products & 21213.2 & 21015.7 & 197.5 \\
\hline 25-30 Six Industries & 140481.9 & 140566.0 & -84.1 \\
\hline 31 Petroleum refining industries & 58993.8 & 56237.3 & 2756.5 \\
\hline 32-50 Nineteen Industries & 154106.3 & 154677.3 & -541.0 \\
\hline 51 Office, computing, and accounting equipment & 161818.9 & 162165.3 & -346.4 \\
\hline 52 Service industry machines & 16141.2 & 16205.4 & -64.2 \\
\hline 53 Electric industrial equipment and apparatuses & 10394.2 & 10507.7 & -113.5 \\
\hline 54 Household appliances & 18686.2 & 18757.9 & -71.7 \\
\hline 55 Electric lighting and wiring equipment & 3619.2 & 3632.9 & -13.7 \\
\hline 56 Radio, TV, and communications equipment & 35124.0 & 35521.3 & -397.3 \\
\hline 57 Electronic components and accessories & 4740.9 & 4608.4 & 132.5 \\
\hline 58 Misc. electrical machinery and equipment & 25372.9 & 25432.6 & -59.7 \\
\hline 59 Motor vehicles and equipment & 185378.9 & 185670.2 & -291.3 \\
\hline 60 Aircraft and parts & 107893.6 & 107916.0 & -22.4 \\
\hline 61 Other transportation equipment & 27720.4 & 27800.8 & -80.4 \\
\hline 62. Scientific and controlling instruments & 78954.1 & 79048.0 & -93.9 \\
\hline 63 Optical, ophthalmic, and photography equipment & 19736.7 & 19827.1 & -90.4 \\
\hline 64 Miscellaneous manufacturing & 25368.0 & 25421.5 & -53.5 \\
\hline 65 Transportation and warehousing & 178391.7 & 178466.7 & -75.0 \\
\hline 66 Communications, except radio and TV & 119583.3 & 119729.3 & -146.0 \\
\hline 67 Radio and TV broadcasting & 19559.2 & 19559.4 & -0.2 \\
\hline 68 Electric, gas, water, and sanitary services & 142219.8 & 138416.4 & 3803.4 \\
\hline 69 Trade & 925122.3 & 926096.5 & -974.2 \\
\hline 70 Finance and insurance services & 306537.5 & 306620.1 & -82.6 \\
\hline 71 Real estate & 575473.4 & 575880.3 & -406.9 \\
\hline 72-76 Five Industries & 617145.7 & 617250.9 & -105.2 \\
\hline 77 Health, education, and social services & 740964.0 & 741166.9 & -202.9 \\
\hline 78-85 Nine Industries & 537882.7 & 537875.7 & 7.0 \\
\hline TOTALS & 6253970.0 & 6254162.8 & -192.8 \\
\hline
\end{tabular}


Table 4.3. Summary of Findings (Various I/O and Labor Intensity Assumptions [In millions except Jobs Difference in units])

\begin{tabular}{|c|c|c|c|c|c|c|}
\hline Year & Base Case & CCAP Case & Difference & Base Case & CCAP Case & Difference \\
\hline & \multicolumn{3}{|c|}{ Labor Intensity 1990} & \multicolumn{3}{|c|}{ Labor Intensity 2005} \\
\hline \multicolumn{7}{|c|}{ Total Jobs } \\
\hline $1990 \mathrm{I} / \mathrm{O}$ & 127.226 & 127.273 & $-47,400$ & 130.284 & 130.340 & $-56,600$ \\
\hline $2005 \mathrm{I} / \mathrm{O}$ & 126.075 & 126.135 & $-60,100$ & 127.237 & 127.307 & $-69,500$ \\
\hline \multicolumn{7}{|c|}{ Total Hours } \\
\hline 1990 V/O & 239435.12 & 239522.79 & -87.67 & 250256.86 & 250367.86 & -111.00 \\
\hline $2005 \mathrm{I} / \mathrm{O}$ & 237674.25 & 237786.59 & -112.34 & 244523.11 & 244658.63 & -135.52 \\
\hline
\end{tabular}

\subsection{Labor Impacts: Results}

The results of the eight sets of calculations are shown Table 4.3. In all cases the results are strikingly similar. Under the total jobs section of the summary findings, there is a difference between the Base Case and the CCAP case of between $-47,400$ and $-69,500$ jobs; the lower number is derived when the 1990 I/O and 1990 labor intensity are used, the higher when both the $2005 \mathrm{I} / \mathrm{O}$ and labor intensity are used. This means that there are between 47,000 and 70,000 more jobs under the CCAP case than under the base case. These results suggest that the CCAP will account for about 60,000 new jobs or about 115 million more hours worked per year in the year 2000 .

The astute reader will notice that the calculations using the I/O table for 1990 should have used final demand vectors in 1987 dollars, because the I/O table is in those units, not in the vectors defined in 1982 dollars. This would give rise to some bizarre results except for the fact that the labor intensities are also defined in 1987 dollars. The same calculation using the $1990 \mathrm{I} / \mathrm{O}$ table (in 1987 dollars) and labor intensities for 1990 (again in 1987 dollars) but using the final demand vectors defined as in Table 4.2 (in 1990 dollars) provides differences that are nearly identical to the results using the I/O table and the labor intensities for 2005. Total jobs under CCAP, for example, are 69,800 more than under the base case (compared to 69,500 ) and hours increase by 130 million rather than the 135.5 million reported above. 


\subsection{References}

Bureau of the Census. See U.S. Department of Commerce. Bureau of the Census.

Bureau of Economic Analysis (BEA). See U.S. Department of Commerce, Bureau of Economic Analysis.

Bureau of Labor Statistics. See U.S. Department of Labor, Bureau of Labor Statistics.

Energy Information Administration. See U.S. Department of Energy, Energy Information Administration.

Jack Faucett Associates. 1989. National Energy Accounts 1958-1985. JACFAU-89-351. Jack Faucett Associates, Bethesda, Maryland.

Office of Management and Budget. 1987. Standard Industrial Classification Manual. National Technical Information Service, Springfield, Virginia.

U.S. Department of Commerce, Bureau of the Census. 1992. 1990 Annual Survey of Manufacturers. Statistics for Industry Groups and Industries. M90(AS)-1. United States Government Printing Office, Washington, D.C. (Available for various, non-census years.)

U.S. Department of Commerce, Bureau of the Census. 1990. 1987 Census of Manufacturers. Industry Series. MC87-I-20D. United States Government Printing Office, Washington, D.C. (Available every five years.)

U.S. Department of Commerce, Bureau of Economic Analysis. 1991. "Benchmark Input-Output Accounts of the United States, 1982." Survey of Current Business. July (71:7), pp. 30-71.

U.S. Department of Commerce, Bureau of Economic Analysis. 1994. Benchmark Input-Output Accounts of the United States, 1987. U.S. Government Printing Office, Washington, D.C.

U.S. Department of Energy, Energy Information Administration (EIA). 1991. Manufacturing Energy Consumption Survey: Consumption of Energy, 1988. DOE/EIA-0512(88). Washington, D.C.

U.S. Department of Energy, Energy Information Administration (EIA). 1994. Manufacturing Consumption of Energy, 1991. DOE/EIA-0512(91). Washington, D.C.

U.S. Department of Labor, Bureau of Labor Statistics, Office of Employment Projections. 1993. OUTLOOK: 1992-2005: Input-Output 228 Order Diskette Documentation. Washington, D.C. 

Appendix

Selected Detailed Tables and Results Files for the Example Application: Employment Implications of the Climate Change Action Plan 



\section{Appendix}

\section{Selected Detailed Tables and Results Files for the Example Application: Employment Implications of the Climate Change Action Plan}

This appendix contains detailed print-outs for the comparison of the two final demand cases using the 1990 table and intensity and for the two cases using the 2005 table and intensity. The first two tables (A.1 and A.2) show the detailed results from these two comparisons. The second set of tables (A.3 and A.4) shows a typical comparison when you request that the results be saved to a file (only the summary results are shown here; the detailed results may also be printed). Finally, Table A.5 shows the details of the base case and CCAP final demand vectors in 1990 dollars, the differences, the values deflated to 1982 dollars, and the final demand deflator. 
Table A.1. Base Case Jobs and Hours Compared to Climate Change Action Plan

\begin{tabular}{|c|c|c|c|c|c|c|c|}
\hline \multicolumn{8}{|c|}{$\begin{array}{l}\text { I/O } 1990 \text { for both Base and CCAP } \\
\text { LI } 1990 \text { for both Base and CCAP }\end{array}$} \\
\hline \multirow[b]{2}{*}{ No. } & \multirow[b]{2}{*}{ Industry } & \multicolumn{2}{|c|}{ Base Case } & \multicolumn{2}{|c|}{ CCAP } & \multicolumn{2}{|c|}{ Difference } \\
\hline & & Jobs & Hours & Jobs & Hours & Jobs & Hours \\
\hline 1 & Livestock & 1.4174 & 3220.843 & 1.4177 & 3221.683 & -0.0003 & -0.8398 \\
\hline 2 & Other agr & 1.144 & 2517.607 & 1.1443 & 2518.271 & -0.0003 & -0.6636 \\
\hline 3 & Forestry & 0.0731 & 162.5146 & 0.0732 & 162.6707 & $-1.0 \mathrm{E}-04$ & -0.1561 \\
\hline 4 & Agricultu & 0.4703 & 1029.944 & 0.4706 & 1030.518 & -0.0003 & -0.5735 \\
\hline 5 & Iron and & 0.0272 & 59.6033 & 0.0272 & 59.6644 & 0 & -0.0611 \\
\hline 6 & Nonferrou & 0.0032 & 6.996 & 0.0032 & 7.0067 & 0 & -0.0107 \\
\hline 7 & Coal mini & 0.0818 & 183.7563 & 0.081 & 181.9393 & 0.0008 & 1.817 \\
\hline 8 & Crude pet & 0.0612 & 131.0846 & 0.058 & 124.1343 & 0.0032 & 6.9503 \\
\hline 9 & Stone and & 0.0494 & 112.9234 & 0.0494 & 112.8748 & 0 & 0.0486 \\
\hline 10 & Chemical & 0.0024 & 5.6175 & 0.0024 & 5.616 & 0 & 0.0015 \\
\hline 11 & New const & 0.5175 & 1163.919 & 0.5193 & 1167.906 & -0.0018 & -3.9872 \\
\hline 12 & Maintenan & 0.0166 & 37.7441 & 0.0166 & .37 .7148 & 0 & 0.0293 \\
\hline 13 & Ordinance & 0.3054 & 639.464 & 0.3049 & 638.4256 & 0.0005 & 1.0384 \\
\hline 14 & Food and & 3.2646 & 6871.332 & 3.2654 & .6873 .034 & -0.0008 & -1.7022 \\
\hline 15 & Tobacco & 0.039 & 79.9334 & 0.039 & 79.947 & 0 & -0.0136 \\
\hline 16 & Broad and & 0.3306 & 691.8021 & 0.3309 & 692.456 & -0.0003 & -0.6539 \\
\hline 17 & Misc. tex & 0.1519 & 327.7877 & 0.1523 & 328.566 & -0.0004 & -0.7783 \\
\hline 18 & Apparel & 1.7981 & 3454.363 & 1.7988 & 3455.693 & -0.0007 & -1.3304 \\
\hline 19 & Misc. fab & 0.3312 & 669.8539 & 0.3315 & 670.3784 & -0.0003 & -0.5245 \\
\hline 20 & Lumber an & 0.5826 & 1218.192 & 0.5839 & 1220.802 & -0.0013 & -2.6103 \\
\hline 21 & Wood cont & 0.0071 & 14.9265 & 0.0071 & 14.9538 & 0 & -0.0273 \\
\hline 22 & Household & 0.7125 & 1436.383 & 0.7159 & 1443.251 & -0.0034 & -6.8677 \\
\hline 23 & Other fur & 0.4985 & 1036.973 & 0.5007 & 1041.578 & -0.0022 & -4.6052 \\
\hline 24 & Paper and & 0.286 & 633.4821 & 0.2855 & 632.3783 & 0.0005 & 1.1038 \\
\hline 25 & Paperboar & 0.1853 & 404.2308 & 0.1853 & 404.3112 & 0 & -0.0804 \\
\hline 26 & Printing & 1.5587 & 3146.577 & 1.5594 & 3147.985 & -0.0007 & -1.4087 \\
\hline 27 & Chemicals & 0.3352 & 730.9066 & 0.3349 & 730.2413 & 0.0003 & 0.6653 \\
\hline 28 & Plastics & 0.1624 & 350.4167 & 0.1625 & 350.6212 & $-1.0 \mathrm{E}-04$ & -0.2045 \\
\hline 29 & Drugs, cl & 0.6059 & 1277.181 & 0.6059 & 1277.047 & 0 & 0.1342 \\
\hline 30 & Paints an & 0.054 & 114.7288 & 0.0541 & 114.8597 & -0.0001 & -0.1309 \\
\hline 31 & Petroleum & 0.2832 & 631.699 & 0.276 & 615.7584 & 0.0072 & 15.9406 \\
\hline 32 & Rubber an & 0.6887 & 1459.93 & 0.6892 & 1461.148 & -0.0005 & -1.2175 \\
\hline 33 & Leather $t$ & 0.0045 & 9.138 & 0.0047 & 9.5779 & -0.0002 & -0.4399 \\
\hline 34 & Footwear & 0.1053 & 207.184 & 0.1056 & 207.6977 & -0.0003 & -0.5137 \\
\hline
\end{tabular}


Table A.1. (contd)

\begin{tabular}{|c|c|c|c|c|c|c|c|}
\hline \multirow[b]{3}{*}{ No. } & \multicolumn{7}{|c|}{$\begin{array}{l}\text { V/O } 1990 \text { for both Base and CCAP } \\
\text { LI } 1990 \text { for both Base and CCAP }\end{array}$} \\
\hline & & \multicolumn{2}{|c|}{ Base Case } & \multicolumn{2}{|c|}{ CCAP } & \multicolumn{2}{|c|}{ Difference } \\
\hline & Industry & Jobs & Hours & Jobs & Hours & Jobs & Hours \\
\hline 35 & Glass and & 0.1471 & 315.178 & 0.1472 & 315.4381 & -0.0001 & -0.2601 \\
\hline 36 & Stone and & 0.4055 & 873.5022 & 0.4062 & 874.9788 & -0.0007 & -1.4766 \\
\hline 37 & Primary i & 0.3699 & 810.9413 & 0.3703 & 811.8192 & -0.0004 & -0.8779 \\
\hline 38 & Primary $n$ & 0.3595 & 778.3444 & 0.36 & 779.5193 & -0.0005 & -1.1749 \\
\hline 39 & Metal con & 0.0558 & 125.5973 & 0.0557 & 125.4882 & 0.0001 & 0.1091 \\
\hline 40 & Fabricate & 0.4591 & 968.9094 & 0.4599 & 970.6609 & -0.0008 & -1.7515 \\
\hline 41 & Screw mac & 0.3055 & 655.1812 & 0.3058 & 655.9042 & -0.0003 & -0.723 \\
\hline 42 & Other fab & 0.4369 & 924.5176 & 0.4376 & 925.9562 & -0.0007 & -1.4386 \\
\hline 43 & Engines a & 0.1233 & 266.7726 & 0.1233 & 266.7395 & 0 & 0.0331 \\
\hline 44 & Farm and & 0.2401 & 512.1072 & 0.241 & 514.0291 & -0.0009 & -1.9219 \\
\hline 45 & Construct & 0.2924 & 635.4653 & 0.2928 . & 636.4799 & -0.0004 & -1.0146 \\
\hline 46 & Materials & 0.1294 & 274.294 & 0.1298 & 275.1289 & -0.0004 & -0.8349 \\
\hline 47 & Metalwork & 0.112 & 243.2275 & 0.1132 & 245.9061 & -0.0012 & -2.6786 \\
\hline 48 & Speciali & 0.2568 & 547.3252 & 0.2575 & 548.9184 & -0.0007 & -1.5932 \\
\hline 49 & General i & 0.6846 & 1472.572 & 0.6856 & 1474.78 & -0.001 & -2.2089 \\
\hline 50 & Misc. mac & 0.104 & 224.2609 & 0.1042 & 224.5347 & -0.0002 & -0.2738 \\
\hline 51 & Office, $c$ & 3.7615 & 7971.841 & 3.7692 & 7988.171 & -0.0077 & -16.3301 \\
\hline 52 & Service i & 0.2427 & 504.9201 & 0.2433 & 506.3255 & -0.0006 & -1.4054 \\
\hline 53 & Electric & 0.3254 & 695.6024 & 0.3266 & 698.1318 & -0.0012 & -2.5294 \\
\hline 54 & Household & 0.2834 & 581.7142 & 0.2844 & 583.7535 & -0.001 & -2.0393 \\
\hline 55 & Electric & 0.1708 & 355.2979 & 0.1711 & 355.9763 & -0.0003 & -0.6784 \\
\hline 56 & Radio. TV & 0.5528 & 1176.484 & 0.5579 & 1187.21 & $-0.0051^{\circ}$ & -10.7255 \\
\hline 57 & Electroni & 0.6914 & 1439.685 & 0.6921 & 1441.065 & -0.0007 & -1.3799 \\
\hline 58 & Misc. ele & 0.3653 & 774.9645 & 0.366 & .776 .4367 & -0.0007 & -1.4722 \\
\hline 59 & Motor veh & 1.8964 & 4117.941 & 1.899 & 4123.624 & -0.0026 & -5.6826 \\
\hline 60 & Aircraft & 1.9991 & 4256.481 & 1.9995 & 4257.239 & -0.0004 & -0.7583 \\
\hline 61 & Other tra & 0.5134 & 1067.588 & 0.5147 & 1070.276 & -0.0013 & -2.6883 \\
\hline 62 & Scientifi & 1.1895 & 2493.895 & 1.1907 & 2496.374 & -0.0012 & -2.4793 \\
\hline 63 & Optical, & 0.2149 & 451.4417 & 0.2155 & 452.6247 & -0.0006 & -1.183 \\
\hline 64 & Miscellan & 0.5816 & 1200.571 & 0.5825 & 1202.468 & -0.0009 & -1.8973 \\
\hline 65 & Transport & 3.4534 & 6969.996 & 3.4517 & 6966.486 & 0.0017 & 3.5098 \\
\hline 66 & Communica & 0.883 & 1873.344 & 0.8837 & 1874.744 & -0.0007 & -1.4001 \\
\hline 67 & Radio and & 0.6573 & 1229.124 & 0.6574 & 1229.351 & $-1.0 \mathrm{E}-04$ & -0.2271 \\
\hline 68 & Electric, & 0.8984 & 1947.051 & 0.8856 & 1919.358 & 0.0128 & 27.6936 \\
\hline 69 & Trade & 24.9764 & 43739.29 & 24.9975 & 43776.13 & -0.0211 & -36.8398 \\
\hline
\end{tabular}


Table A.1. (contd)

\begin{tabular}{||c|l|c|c|c|c|c|c||}
\hline \multicolumn{7}{|c|}{$\begin{array}{c}\text { I/O 1990 for both Base and CCAP } \\
\text { LI 1990 for both Base and CCAP }\end{array}$} \\
\hline \multirow{2}{*}{ No. } & Industry & Jobs & Hours & Jobs & Hours & Jobs & Hours \\
\hline & \multicolumn{2}{|c|}{ Base Case } & \multicolumn{2}{c||}{ CCAP } & Difference \\
\hline 70 & Finance a & 5.2902 & 10020.91 & 5.2901 & 10020.62 & 0.0001 & 0.2881 \\
\hline 71 & Real esta & 1.2943 & 2483.634 & 1.2943 & 2483.719 & 0 & -0.0845 \\
\hline 72 & Hotel and & 3.5591 & 6280.34 & 3.5599 & 6281.831 & -0.0008 & -1.4908 \\
\hline 73 & Business & 7.9556 & 14779.42 & 7.9577 & 14783.34 & -0.0021 & -3.9228 \\
\hline 74 & Eating an & 8.232 & 11053.06 & 8.2322 & 11053.32 & -0.0002 & -0.2588 \\
\hline 75 & Automobil & 1.7769 & 3485.847 & 1.7772 & 3486.432 & -0.0003 & -0.5852 \\
\hline 76 & Amusement & 1.2449 & 1953.017 & 1.2452 & 1953.439 & -0.0003 & -0.4223 \\
\hline 77 & Health, e & 19.3815 & 33291.92 & 19.3864 & 33300.3 & -0.0049 & -8.3789 \\
\hline 78 & Federal g & 0.5881 & 1228.148 & 0.5878 & 1227.565 & 0.0003 & 0.5823 \\
\hline 79 & State and & 1.0437 & 2213.289 & 1.0414 & 2208.417 & 0.0023 & 4.8728 \\
\hline 80 & Noncompar & 0 & 0 & 0 & 0 & 0 & 0 \\
\hline 81 & Scrap & 0 & 0 & 0 & 0 & 0 & 0 \\
\hline 82 & Governmen & 12.563 & 26131.02 & 12.563 & 26131.02 & 0 & 0 \\
\hline 83 & Rest of t & 0 & 0 & 0 & 0 & 0 & 0 \\
\hline 84 & Household & 0 & 0 & 0 & 0 & 0 & 0 \\
\hline 85 & Inventory & 0 & 0 & 0 & -0 & 0 & 0 \\
\hline 86 & Total & 127.2258 & 239435.1 & 127.2732 & 239522.7 & -0.0474 & -87.671 \\
\hline
\end{tabular}


Table A.2. Base Case Jobs and Hours Compared to Climate Change Action Plan

\begin{tabular}{|c|c|c|c|c|c|c|c|}
\hline \multicolumn{8}{|c|}{$\begin{array}{l}\text { I/O } 2005 \text { for Both Base and CCAP } \\
\text { LI } 2005 \text { for both Base and CCAP }\end{array}$} \\
\hline & & \multicolumn{2}{|c|}{ Base Case } & \multicolumn{2}{|c|}{ CCAP } & \multicolumn{2}{|c|}{ Difference } \\
\hline No. & Industry & Jobs & Hours & Jobs & Hours & Jobs & Hours \\
\hline 1 & Livestock & 2.4997 & 5679.011 & 2.5005 & 5680.668 & -0.0008 & -1.6568 \\
\hline 2 & Other agr & 2.6411 & 5811.958 & 2.6419 & 5813.693 & -0.0008 & -1.7349 \\
\hline 3 & Forestry & 0.2778 & 617.1246 & 0.2781 & 617.8082 & -0.0003 & -0.6836 \\
\hline 4 & Agricultu & 1.5565 & 3407.973 & 1.5575 & 3410.187 & -0.001 & -2.2139 \\
\hline 5 & Iron and & 0.0221 & 48.4385 & 0.0221 & 48.5104 & 0 & -0.0719 \\
\hline 6 & Nonferrou & 0.0022 & 5.0185 & 0.0022 & 5.0289 & 0 & -0.0104 \\
\hline 7 & Coal mini & 0.1269 & 286.4341 & 0.1258 & 283.8192 & 0.0011 & 2.6149 \\
\hline 8 & Crude pet & 0.0768 & 163.9854 & 0.0751 & 160.2155 & 0.0017 & 3.7699 \\
\hline 9 & Stone and & 0.0274 & 62.6111 & 0.0274 & 62.6335 & 0 & -0.0224 \\
\hline 10 & Chemical & 0.0034 & 7.8244 & 0.0034 & 7.8282 & 0 & -0.0038 \\
\hline 11 & New const & 5.2229 & 11857.38 & 5.2392 & 11894.41 & -0.0163 & -37.0322 \\
\hline 12 & Maintenan & 0.5303 & 1163.758 & 0.5301 & 1163.416 & 0.0002 & 0.3425 \\
\hline 13 & Ordinance & 0.1239 & 254.7377 & 0.1237 & 254.3299 & 0.0002 & 0.4078 \\
\hline 14 & Food and & 1.2915 & 2714.343 & 1.2919 & 2715.092 & -0.0004 & -0.7493 \\
\hline 15 & Tobacco & 0.0222 & 45.4138 & 0.0222 & 45.4214 & 0 & -0.0076 \\
\hline 16 & Broad and & 0.3461 & 723.7605 & 0.3464 & 724.4883 & -0.0003 & -0.7278 \\
\hline 17 & Misc. tex & 0.099 & 213.376 & 0.0992 & 213.8897 & -0.0002 & -0.5137 \\
\hline 18 & Apparel & 0.4944 & 949.9213 & 0.4946 & 950.2973 & -0.0002 & -0.376 \\
\hline 19 & Misc. fab & 0.107 & 216.6199 & 0.1071 & 216.7955 & -0.0001 & -0.1756 \\
\hline 20 & Lumber an & 1.1696 & 2508.202 & 1.1721 & 2513.505 & -0.0025 & -5.303 \\
\hline 21 & Wood cont & 0.0165 & 34.8027 & 0.0165 & 34.8678 & 0 & -0.0651 \\
\hline 22 & Household & 0.2229 & 449.51 & 0.224 & 451.6324 & -0.0011 & -2.1224 \\
\hline 23 & Other fur & 0.1474 & 306.7733 & 0.1481 & 308.1426 & -0.0007 & -1.3693 \\
\hline 24 & Paper and & 0.4501 & 998.0058 & 0.4497 & 997.0176 & 0.0004 & 0.9882 \\
\hline 25 & Paperboar & 0.1686 & 367.8141 & 0.1687 & 368.0372 & $-1.0 \mathrm{E}-04$ & -0.2231 \\
\hline 26 & Printing & 1.3436 & 2712.461 & 1.3444 & 2714.109 & -0.0008 & -1.6475 \\
\hline 27 & Chemicals & 0.3322 & 724.245 & 0.3321 & 724.2108 & 0.0001 & 0.0342 \\
\hline 28 & Plastics & 0.1464 & 315.8497 & 0.1465 & 316.1121 & -0.0001 & -0.2624 \\
\hline 29 & Drugs, cl & 0.3296 & 694.9766 & 0.3297 & 695.0552 & -0.0001 & -0.0786 \\
\hline 30 & Paints an & 0.0538 & 114.2356 & 0.0538 & 114.3841 & 0 & -0.1485 \\
\hline 31 & Petroleum & 0.1289 & 285.3006 & 0.1267 & 280.4814 & 0.0022 & 4.8192 \\
\hline 32 & Rubber an & 0.2706 & 544.8731 & 0.2709 & 545.4358 & -0.0003 & -0.5627 \\
\hline 33 & Leather $t$ & 0.0009 & 1.7864 & 0.0009 & 1.8741 & 0 & -0.0877 \\
\hline 34 & Footwear & 0.0017 & 3.4015 & 0.0017 & 3.4097 & 0 & -0.0082 \\
\hline
\end{tabular}


Table A.2. (contd)

\begin{tabular}{|c|c|c|c|c|c|c|c|}
\hline \multicolumn{8}{|c|}{$\begin{array}{l}\text { I/O } 2005 \text { for Both Base and CCAP } \\
\text { LI } 2005 \text { for both Base and CCAP }\end{array}$} \\
\hline \multirow[b]{2}{*}{ No. } & \multirow[b]{2}{*}{ Industry } & \multicolumn{2}{|c|}{ Base Case } & \multicolumn{2}{|c|}{ CCAP } & \multicolumn{2}{|c|}{ Difference } \\
\hline & & Jobs & Hours & Jobs & Hours & Jobs & Hours \\
\hline 35 & Glass and & 0.0073 & 15.68 & 0.0073 & 15.7016 & 0 & -0.0216 \\
\hline 36 & Stone and & 0.0858 & 141.4406 & 0.086 & 141.7089 & -0.0002 & -0.2683 \\
\hline 37 & Primary i & 3.394 & 7253.293 & 3.399 & 7263.929 & -0.005 & -10.6362 \\
\hline 38 & Primary $n$ & 1.5485 & 3405.981 & 1.5513 & 3411.951 & -0.0028 & -5.9698 \\
\hline 39 & Metal con & 0.0393 & 88.5409 & 0.0393 & 88.5198 & 0 & 0.0211 \\
\hline 40 & Fabricate & 0.4598 & 970.2691 & 0.4608 & 972.3594 & -0.001 & -2.0903 \\
\hline 41 & Screw mac & 0.2578 & 553.2466 & 0.2581 & 553.8946 & -0.0003 & -0.648 \\
\hline 42 & Other fab & 0.438 & 926.9031 & 0.4388 & 928.7079 & -0.0008 & -1.8048 \\
\hline 43 & Engines a & 0.1206 & 260.6893 & 0.1206 & 260.6629 & 0 & 0.0264 \\
\hline 44 & Farm and & 0.1451 & 309.503 & 0.1456 & 310.6912 & -0.0005 & -1.1882 \\
\hline 45 & Construct & 0.1754 & 381.2212 & 0.1757 & 381.9181 & -0.0003 & -0.6969 \\
\hline 46 & Materials & 0.0998 & 211.5132 & 0.1001 & 212.172 & -0.0003 & -0.6588 \\
\hline 47 & Metalwork & 0.0972 & 207.9142 & 0.0983 & 210.354 & -0.0011 & -2.4398 \\
\hline 48 & Special i & 0.2 & 426.1737 & 0.2006 & 427.5222 & -0.0006 & -1.3485 \\
\hline 49 & General i & 0.6325 & 1356.26 & 0.6336 & 1358.486 & -0.0011 & -2.2264 \\
\hline 50 & Misc. mac & 0.0202 & 43.7117 & 0.0202 & 43.755 & 0 & -0.0433 \\
\hline 51 & Office, $c$ & 1.6885 & 3673.286 & 1.6919 & 3680.789 & -0.0034 & -7.5027 \\
\hline 52 & Service i & 0.0956 & 199.1913 & 0.0959 & 199.7387 & -0.0003 & -0.5474 \\
\hline 53 & Electric & 0.0731 & 153.844 & 0.0734 & 154.5062 & -0.0003 & -0.6622 \\
\hline 54 & Household & 0.0642 & 131.9769 & 0.0644 & 132.4409 & -0.0002 & -0.464 \\
\hline 55 & Electric & 0.0947 & 196.9264 & 0.0949 & 197.3066 & -0.0002 & -0.3802 \\
\hline 56 & Radio, TV & 0.1416 & 301.5116 & 0.1428 & 303.9682 & -0.0012 & -2.4566 \\
\hline 57 & Electroni & 0.254 & 529.4594 & 0.2543 & 529.9376 & -0.0003 & -0.4782 \\
\hline 58 & Misc. ele & 0.0991 & 210.4862 & 0.0993 & 210.8669 & -0.0002 & -0.3807 \\
\hline 59 & Motor veh & 2.0031 & 4238.751 & 2.006 & 4244.815 & -0.0029 & -6.0644 \\
\hline 60 & Aircraft & 1.6215 & 3451.833 & 1.6218 & 3452.483 & -0.0003 & -0.6504 \\
\hline 61 & Other tra & 0.2648 & 551.928 & 0.2655 & 553.3797 & -0.0007 & -1.4517 \\
\hline 62 & Scientifi & 0.7445 & 1558.647 & 0.7453 & 1560.308 & -0.0008 & -1.6608 \\
\hline 63 & Optical, & 0.157 & 329.4598 & 0.1574 & 330.3468 & -0.0004 & -0.887 \\
\hline 64 & Miscellan & 0.1863 & 384.7673 & 0.1866 & 385.3927 & -0.0003 & -0.6254 \\
\hline 65 & Transport & 3.1368 & 6334.903 & 3.1369 & 6335.017 & -0.0001 & -0.1143 \\
\hline 66 & Communica & 0.9852 & 2090.239 & 0.986 & 2092.006 & -0.0008 & -1.7675 \\
\hline 67 & Radio and & 0.2731 & 510.8904 & 0.2732 & 511.0763 & $-1.0 \mathrm{E}-04$ & -0.1859 \\
\hline 68 & Electric, & 0.9137 & 1983.075 & 0.9009 & 1955.405 & 0.0128 & 27.6702 \\
\hline 69 & Trade & 27.201 & 47620 & 27.2264 & 47664.54 & -0.0254 & .5313 \\
\hline
\end{tabular}


Table A.2. (contd)

\begin{tabular}{|c|c|c|c|c|c|c|c|}
\hline \multicolumn{8}{|c|}{$\begin{array}{l}\text { y/O } 2005 \text { for Both Base and CCAP } \\
\text { LI } 2005 \text { for both Base and CCAP }\end{array}$} \\
\hline & & \multicolumn{2}{|c|}{ Base Case } & \multicolumn{2}{|c|}{ CCAP } & \multicolumn{2}{|c|}{ Difference } \\
\hline No. & Industry & Jobs & Hours & Jobs & Hours & Jobs & Hours \\
\hline 70 & Finance a & 5.2157 & 9876.104 & 5.2161 & 9876.783 & -0.0004 & -0.6797 \\
\hline 71 & Real esta & 1.4022 & 2686.099 & 1.4025 & 2686.789 & -0.0003 & -0.6897 \\
\hline 72 & Hotel and & 2.8896 & 5098.724 & 2.8904 & 5100.151 & -0.0008 & -1.4278 \\
\hline 73 & Business & 10.5324 & 19566.24 & 10.5378 & 19576.2 & -0.0054 & -9.9609 \\
\hline 74 & Eating an & 6.0702 & 8152.157 & 6.0708 & 8153.048 & -0.0006 & -0.8911 \\
\hline 75 & Automobil & 1.6548 & 3245.479 & 1.6553 & 3246.392 & -0.0005 & -0.9133 \\
\hline 76 & Amusement & 1.5881 & 2492.312 & 1.5886 & 2493.016 & -0.0005 & -0.7041 \\
\hline 77 & Health, e & 11.4852 & 19735.91 & 11.4884 & 19741.28 & -0.0032 & -5.3672 \\
\hline 78 & Federal $\mathrm{g}$ & 0.2718 & 567.6454 & 0.2718 & 567.6885 & 0 & -0.0431 \\
\hline 79 & State and & 1.2967 & 2749.393 & 1.2952 & 2746.201 & 0.0015 & 3.1921 \\
\hline 80 & Noncompar & 0 & 0 & 0 & 0 & 0 & 0 \\
\hline 81 & Scrap & 0 & 0 & 0 & 0 & 0 & 0 \\
\hline 82 & Governmen & 16.8543 & 35057.61 & 16.8543 & 35057.61 & 0 & 0 \\
\hline 83 & Rest of $t$ & 0 & 0 & 0 & 0 & 0 & 0 \\
\hline 84 & Household & 0 & 0 & 0 & 0 & 0 & 0 \\
\hline 85 & Inventory & 0 & 0 & 0 & 0 & 0 & 0 \\
\hline 86 & Total & 127.2374 & 244523.1 & 127.3067 & 244658.6 & -0.0695 & -135.5 \\
\hline
\end{tabular}


Table A.3. Typical Comparison of the 2000 Base Case With 2000 CCAP Final Demands Results Saved to a File (Using 1990 Input-Output Table and Intensity)

Specifications and Results:

Date: 08-14-1995

Time: $16: 46: 39$

Case 1 specifications:

GDP: C:SEADSWBFGP1990.DBF

Final demand: C:SEADSDBFFDD2000B.DBF

IO table: C:SEADSIDBFCOREVO8790.DBF

Energy intensity: C:ISEADSDBFCOREEI1987.DBF

Labor intensity: C:SSEADSDBFCORELI8790.DBF

Jobs multiplier: C:SEADSDBFLM1990.DBF

Hours multiplier: C:ISEADSDBFHM1990.DBF

Labor region: US

Results: Labor use

Results units:

Jobs -- Millions

Hours - Millions

Case 2 specifications:

Date: 08-14-1995

Time: 11:02:11

Case files selected:

GDP: C:ISEADSDBFGP1990.DBF

Final demand: C:SEADSDBFFDD2000C.DBF

IO table: C:SSEADSDBFCORENO8790.DBF

Energy intensity: C:ISEADSWBFEIDUM.DBF

Labor intensity: C:SSEADSDBFCORELI8790.DBF

Jobs multiplier: C:SSEADSDBFLM1990.DBF

Hours multiplier: C:SEADSDBFHM1990.DBF

Labor region: US

Results: Labor use

A.8 
Table A.3. (contd)

\begin{tabular}{||l|l|r|r||}
\hline \hline & \multicolumn{5}{|c|}{ Case 1 } & Case 2 & \multicolumn{1}{|c||}{ Difference } \\
\hline Jobs & $1.27 \mathrm{E}+02$ & $1.27 \mathrm{E}+02$ & $-4.74 \mathrm{E}-02$ \\
\hline Hours & $2.39 \mathrm{E}+05$ & $2.40 \mathrm{E}+05$ & $-8.77 \mathrm{E}+01$ \\
\hline Industry & Jobs 1 & Jobs 2 & Jobs Diff. \\
\hline Agriculture & $3.10 \mathrm{E}+00$ & $3.11 \mathrm{E}+00$ & $-1.00 \mathrm{E}-03$ \\
\hline Mining & $2.25 \mathrm{E}-01$ & $2.21 \mathrm{E}-01$ & $4.00 \mathrm{E}-03$ \\
\hline Construction & $5.34 \mathrm{E}-01$ & $5.36 \mathrm{E}-01$ & $-1.80 \mathrm{E}-03$ \\
\hline Manufacturing & $2.96 \mathrm{E}+01$ & $2.96 \mathrm{E}+01$ & $-3.53 \mathrm{E}-02$ \\
\hline Services & $4.87 \mathrm{E}+01$ & $4.87 \mathrm{E}+01$ & $-8.50 \mathrm{E}-03$ \\
\hline Other & $4.51 \mathrm{E}+01$ & $4.51 \mathrm{E}+01$ & $-4.80 \mathrm{E}-03$ \\
\hline Total & $1.27 \mathrm{E}+02$ & $1.27 \mathrm{E}+02$ & $-4.74 \mathrm{E}-02$ \\
\hline & & & \\
\hline Industry & Hours 1 & Hours 2 & Hours Diff. \\
\hline Agriculture & $6.93 \mathrm{E}+03$ & $6.93 \mathrm{E}+03$ & $-2.23 \mathrm{E}+00$ \\
\hline Mining & $5.00 \mathrm{E}+02$ & $4.91 \mathrm{E}+02$ & $8.75 \mathrm{E}+00$ \\
\hline Construction & $1.20 \mathrm{E}+03$ & $1.21 \mathrm{E}+03$ & $-3.96 \mathrm{E}+00$ \\
\hline Manufacturing & $6.21 \mathrm{E}+04$ & $6.22 \mathrm{E}+04$ & $-7.36 \mathrm{E}+01$ \\
\hline Services & $8.33 \mathrm{E}+04$ & $8.34 \mathrm{E}+04$ & $-1.49 \mathrm{E}+01$ \\
\hline Other & $8.53 \mathrm{E}+04$ & $8.53 \mathrm{E}+04$ & $-1.81 \mathrm{E}+00$ \\
\hline Total & $2.39 \mathrm{E}+05$ & $2.40 \mathrm{E}+05$ & $-8.77 \mathrm{E}+01$ \\
\hline \hline
\end{tabular}


Table A.4. Typical Comparison of the 2000 Base Case with 2000 CCAP Results Saved to a File (Using 2005 Input-Output Table and Intensity)

\section{Specifications and Results:}

Date: 08-14-1995

Time: $16: 44: 52$

Case 1 specifications:

GDP: C:ISEADSDBFIGP1990.DBF

Final demand: C:SEADSWBFFDD2000B.DBF

IO table: C:ISEADSIDBFCOREVO2005.DBF

Energy intensity: C:ISEADSDBFCOREEI1987.DBF

Labor intensity: C:SEADSIDBFCORELL2005.DBF

Jobs multiplier: C:SEADSDBFLM1990.DBF

Hours multiplier: C:SEADSDBFHM1990.DBF

Labor region: US

Results: Labor use

Results units:

Jobs -- Millions

Hours - Millions

Case 2 specifications:

Date: 08-14-1995

Time: 10:06:46

Case files selected:

GDP: C:ISEADSDBFWP1990.DBF

Final demand: C:SEADSWBFFDD2000C.DBF

IO table: C:SEADSUDBFCOREVO2005.DBF

Energy intensity: C:SEADSDBFEIDUM.DBF

Labor intensity: C:ISEADSDBFCORELI2005.DBF

Jobs multiplier: C:ISEADSDBFLM1990.DBF

Hours multiplier: C:SEADSUBFHM1990.DBF

Labor region: US

Results: Labor use 
Table A.4. (contd)

\begin{tabular}{|c|c|c|c|}
\hline \multicolumn{4}{|c|}{ Summary Results: } \\
\hline & Case 1 & Case 2 & Difference \\
\hline Jobs & $1.27 \mathrm{E}+02$ & $1.27 E+02$ & $-6.93 \mathrm{E}-02$ \\
\hline Hours & $2.45 E+05$ & $2.45 E+05$ & $-1.36 E+02$ \\
\hline Industry & Jobs 1 & Jobs 2 & Jobs Diff. \\
\hline Agriculture & $6.98 \mathrm{E}+00$ & $6.98 \mathrm{E}+00$ & $-2.90 \mathrm{E}-03$ \\
\hline Mining & $2.59 \mathrm{E}-01$ & $2.56 \mathrm{E}-01$ & $2.80 \mathrm{E}-03$ \\
\hline Construction & $5.75 E+00$ & $5.77 \mathrm{E}+00$ & $-1.61 \mathrm{E}-02$ \\
\hline Manufacturing & $2.25 \mathrm{E}+01$ & $2.25 \mathrm{E}+01$ & $-2.95 \mathrm{E}-02$ \\
\hline Services & $4.08 \mathrm{E}+01$ & $4.08 E+01$ & $-1.17 \mathrm{E}-02$ \\
\hline Other & $5.09 \mathrm{E}+01$ & $5.09 \mathrm{E}+01$ & $-1.21 \mathrm{E}-02$ \\
\hline Total & $1.27 \mathrm{E}+02$ & $1.27 E+02$ & $-6.93 E-02$ \\
\hline Industry & Hours 1 & Hours 2 & Hours Diff. \\
\hline Agriculture & $1.55 E+04$ & $1.55 \mathrm{E}+04$ & $-6.29 E+00$ \\
\hline Mining & $5.74 \mathrm{E}+02$ & $5.68 E+02$ & $6.28 \mathrm{E}+00$ \\
\hline Construction & $1.30 \mathrm{E}+04$ & $1.31 E+04$ & $-3.67 E+01$ \\
\hline Manufacturing & $4.76 E+04$ & 4.77E+04 & $-6.24 \mathrm{E}+01$ \\
\hline Services & $7.09 \mathrm{E}+04$ & $7.09 E+04$ & $-2.06 E+01$ \\
\hline Other & $9.69 \mathrm{E}+04$ & $9.69 \mathrm{E}+04$ & $-1.58 \mathrm{E}+01$ \\
\hline Total & $2.45 \mathrm{E}+05$ & $2.45 E+05$ & $-1.36 \mathrm{E}+02$ \\
\hline
\end{tabular}


Table A.5. Final Demands for the Climate Change Action Plan Analysis (1990 Dollar Values in Millions, Deflator, and 1982

Dollar Values in Millions.)

\begin{tabular}{|c|c|c|c|c|c|c|c|c|}
\hline \multirow[b]{2}{*}{ No. } & \multirow[b]{2}{*}{ Industry description } & \multirow[b]{2}{*}{ Base } & \multirow[b]{2}{*}{ CCAP } & \multirow[b]{2}{*}{ Diff } & \multirow[b]{2}{*}{ Deflator } & \multicolumn{3}{|c|}{ Deflated FD, 2000} \\
\hline & & & & & & Base & CCAP & Diff \\
\hline 1 & Livestock and livestock products & 4793.43 & 4794.83 & -1.40 & 1.07 & 4459.84 & 4461.14 & -1.30 \\
\hline 2 & Other agricultural products & 41867.98 & 41877.08 & -9.10 & 1.18 & 35505.41 & 35513.13 & -7.72 \\
\hline 3 & Forestry and fishery products & -2106.40 & -2109.10 & 2.70 & 1.32 & -1598.66 & -1600.71 & 2.05 \\
\hline 4 & Agricultural, forestry, and fishery services & 1544.02 & 1548.02 & -4.00 & 1.20 & 1281.99 & 1285.31 & -3.32 \\
\hline 5 & Iron and ferroalloy ore mining & -472.20 & -472.20 & 0.00 & 0.92 & -515.78 & -515.78 & 0.00 \\
\hline 6 & Nonferrous metal ore mining & -63.90 & -59.00 & -4.90 & 0.92 & -69.80 & -64.44 & -5.35 \\
\hline 7 & Coal mining & 5363.75 & 5316.95 & 46.80 & 0.82 & 6551.71 & 6494.54 & 57.17 \\
\hline 8 & Crude petroleum and natural gas & -41222.60 & -41222.60 & 0.00 & 0.72 & -63147.37 & -63147.37 & 0.00 \\
\hline 9 & Stone and clay mining and quarrying & $=215.60$ & -215.90 & 0.30 & 1.18 & -183.47 & -183.73 & 0.26 \\
\hline 10 & Chemical and fertilizer mineral mining & -2.40 & -1.60 & -0.80 & 1.18 & -2.04 & -1.36 & -0.68 \\
\hline 11 & New construction & 512510.15 & 514858.55 & -2348.40 & 1.21 & 423492.11 & 425432.61 & -1940.51 \\
\hline 12 & Maintenance and repair construction & 60522.28 & 60633.18 & -110.90 & 1.24 & 48643.53 & 48732.66 & -89.13 \\
\hline 13 & Ordinance and accessories & 23217.83 & 23171.63 & 46.20 & 1.10 & 21189.95 & 21147.78 & 42.16 \\
\hline 14 & Food and kindred products & 249208.18 & 249278.98 & -70.80 & 1.22 & 203451.85 & 203509.66 & -57.80 \\
\hline 15 & Tobacco & 20723.17 & 20726.57 & -3.40 & 2.08 & 9985.15 & 9986.78 & -1.64 \\
\hline 16 & Broad and narrow fabrics & 598.48 & 599.38 & -0.90 & 1.14 & 525.90 & 526.69 & -0.79 \\
\hline 17 & Misc textiles and flooring & 8410.83 & 8440.53 & -29.70 & 1.17 & 7192.43 & 7217.83 & -25.40 \\
\hline 18 & Apparel & 52395.53 & 52415.03 & -19.50 & 1.15 & 45676.51 & 45693.51 & -17.00 \\
\hline 19 & Misc fabricated textiles & 10619.60 & 10626.40 & -6.80 & 1.11 & 9560.31 & 9566.43 & -6.12 \\
\hline 20 & Lumber and wood products & 1410.62 & 1415.32 & -4.70 & 1.32 & 1070.93 & 1074.49 & -3.57 \\
\hline 21 & Wood containers & 84.68 & 84.68 & 0.00 & 1.21 & 70.23 & 70.23 & 0.00 \\
\hline 22 & Household furniture & 21587.74 & 21693.14 & -105.40 & 1.25 & 17253.62 & 17337.86 & -84.24 \\
\hline 23 & Other fumiture and fixures & 24570.68 & 24689.28 & -118.60 & 1.32 & 18635.33 & 18725.28 & -89.95 \\
\hline 24 & Paper and allied products & 21213.15 & 21015.65 & 197.50 & 1.32 & 16092.52 & 15942.69 & 149.83 \\
\hline 25 & Paperboard containers and boxes & 1839.91 & 1840.61 & -0.70 & 1.32 & 1396.52 & 1397.05 & -0.53 \\
\hline 26 & Printing and publishing & 41592.93 & 41633.63 & -40.70 & 1.44 & 28833.92 & 28862.13 & -28.21 \\
\hline 27 & Chemicals and selected products & 16188.23 & 16199.13 & -10.90 & 1.15 & 14060.82 & 14070.29 & -9.47 \\
\hline 28 & Plastics and synthetic materials & 8948.05 & 8948.05 & 0.00 & 1.22 & 7356.18 & 7356.18 & 0.00 \\
\hline 29 & Drugs. cleaning and toilet preparations & 70455.57 & 70485.87 & -30.30 & 1.39 & 50603.73 & 50625.49 & -21.76 \\
\hline 30 & Paints and allied products & 1457.19 & 1458.69 & -1.50 & 1.28 & 1140.66 & 1141.83 & -1.17 \\
\hline 31 & Petroleum refining industries & 58993.81 & 56237.31 & 2756.50 & 0.79 & 74911.82 & 71411.55 & 3500.27 \\
\hline 32 & Rubber and misc. plastics & 13402.52 & 13411.32 & -8.80 & 1.17 & 11468.87 & 11476.40 & -7.53 \\
\hline 33 & Leather tanning and finishing & 10.41 & 30.81 & -20.40 & 1.44 & 7.24 & 21.44 & -14.20 \\
\hline 34 & Footwear and other leather products & 1829.71 & 1834.71 & -5.00 & 1.35 & 1354.54 & 1358.24 & -3.70 \\
\hline 35 & Glass and glass products & 2702.98 & 2718.58 & -15.60 & 1.19 & 2266.08 & 2279.15 & -13.08 \\
\hline 36 & Stone and clay products & 1732.65 & 1743.45 & -10.80 & 1.15 & 1509.14 & 1518.55 & -9.41 \\
\hline 37 & Primary iron and steel $\mathrm{mfg}$ & -9043.92 & -9044.02 & 0.10 & 1.18 & -7636.51 & -7636.60 & 0.08 \\
\hline 38 & Primary nonferrous metal $\mathrm{mfg}$ & -1498.19 & -1495.49 & -2.70 & 1.33 & -1129.43 & -1127.40 & -2.04 \\
\hline 39 & Metal containers & 357.30 & 357.70 & -0.40 & 1.12 & 318.34 & 318.69 & -0.36 \\
\hline 40 & Fabricated structural metal products & 7922.64 & 7947.14 & -24.50 & 1.21 & 6525.52 & 6545.70 & -20.18 \\
\hline
\end{tabular}


Table A.5. (contd)

\begin{tabular}{|c|c|c|c|c|c|c|c|c|}
\hline \multirow[b]{2}{*}{ No. } & \multirow[b]{2}{*}{ Industry description } & \multirow{2}{*}{ Base } & \multirow[b]{2}{*}{ CCAP } & \multirow[b]{2}{*}{ Diff } & \multirow[b]{2}{*}{ Deflator } & \multicolumn{3}{|c|}{ Deflated FD, 2000} \\
\hline & & & & & & Base & CCAP & Diff \\
\hline 41 & Screw machine products and stampings & 5232.25 & 5231.65 & 0.60 & 1.18 & 4420.62 & 4420.11 & 0.51 \\
\hline 42 & Other fabricated metal products & 6490.94 & 6537.54 & -46.60 & 1.25 & 5210.26 & 5247.67 & -37.41 \\
\hline 43 & Engines and turbines & 9812.06 & 9825.56 & -13.50 & 1.25 & 7869.79 & 7880.62 & -10.83 \\
\hline 44 & Farm and garden machinery & 18562.49 & 18641.79 & -79.30 & 1.21 & 15297.92 & 15363.27 & -65.35 \\
\hline 45 & Construction and mining machinery & 22992.41 & 23052.81 & -60.40 & 1.16 & 19752.93 & 19804.82 & -51.89 \\
\hline 46 & Materials handling machinery and eq. & 7769.14 & 7800.54 & -31.40 & 1.16 & 6718.97 & 6746.12 & -27.16 \\
\hline 47 & Metalworking machinery and equipment & 4851.28 & 4944.48 & -93.20 & 1.22 & 3981.36 & 4057.85 & -76.49 \\
\hline 48 & Special industry machinery and eq. & 21071.27 & 21154.97 & -83.70 & 1.30 & 16223.64 & 16288.09 & -64.44 \\
\hline 49 & General industrial machinery and eq. & 37848.29 & 37922.59 & -74.30 & 1.24 & 30633.98 & 30694.12 & -60.14 \\
\hline 50 & Misc. machinery except electrical & 2060.26 & 2061.26 & -1.00 & 1.22 & 1690.26 & 1691.08 & -0.82 \\
\hline 51 & Office, computing, and accounting eq. & 161818.93 & 162165.33 & -346.40 & 0.46 & 353108.28 & 353864.17 & -755.89 \\
\hline 52 & Service industry machines & 16141.20 & 16205.40 & -64.20 & 1.23 & 13164.67 & 13217.03 & -52.36 \\
\hline 53 & Electric industrial eq and apparatus & 10394.19 & 10507.69 & -113.50 & 1.23 & 8438.21 & 8530.35 & -92.14 \\
\hline 54 & Household appliances & 18686.25 & 18757.95 & -71.70 & 1.14 & 16459.30 & 16522.46 & -63.16 \\
\hline 55 & Electric lighting and wiring equipment & 3619.18 & 3632.88 & -13.70 & 1.27 & 2846.39 & 2857.16 & -10.77 \\
\hline 56 & Radio, TV, and communications eq. & 35124.02 & 35521.32 & -397.30 & 1.10 & 32012.41 & 32374.51 & -362.10 \\
\hline 57 & Electronic components and accessories & 4740.89 & 4608.39 & 132.50 & 1.05 & 4533.26 & 4406.57 & 126.70 \\
\hline 58 & Misc. electrical machinery and supplies & 25372.86 & 25432.56 & -59.70 & 1.10 & 22995.16 & 23049.27 & -54.11 \\
\hline 59 & Motor vehicles and equipment & 185378.92 & 185670.22 & -291.30 & 1.17 & 158389.37 & 158638.26 & -248.89 \\
\hline 60 & Aircraft and parts & 107893.63 & 107916.03 & -22.40 & 1.21 & 88874.49 & 88892.94 & -18.45 \\
\hline 61 & Other transportation equipment & 27720.35 & 27800.75 & -80.40 & 1.26 & 22070.35 & 22134.36 & -64.01 \\
\hline 62 & Scientific and controlling instruments & 78954.08 & 79047.98 & -93.90 & 1.21 & 65245.91 & 65323.51 & -77.60 \\
\hline 63 & Optical, ophthalmic, and photographic eq. & 19736.75 & 19827.15 & -90.40 & 1.11 & 17709.06 & 17790.17 & -81.11 \\
\hline 64 & Miscellaneous manufacturing & 25368.01 & 25421.51 & -53.50 & 1.20 & 21152.34 & 21196.95 & -44.61 \\
\hline 65 & Transportation and warehousing & 178391.72 & 178466.72 & -75.00 & 1.23 & 145128.31 & 145189.33 & -61.02 \\
\hline 66 & Communications, except radio and TV & 119583.31 & 119729.31 & -146.00 & 1.34 & 89227.95 & 89336.89 & -108.94 \\
\hline 67 & Radio and TV broadcasting & 19559.21 & 19559.41 & -0.20 & 1.44 & 13583.73 & 13583.87 & -0.14 \\
\hline 68 & Electric, gas, water, and sanitary services & 142219.80 & 138416.40 & 3803.40 & 1.15 & 124057.75 & 120740.06 & 3317.69 \\
\hline 69 & Trade & 925122.29 & 926096.49 & -974.20 & 1.20 & 771128.03 & 771940.06 & -812.04 \\
\hline 70 & Finance and insurance services & 306537.50 & 306620.10 & -82.60 & 1.46 & 210562.92 & 210619.66 & -56.74 \\
\hline 71 & Real estate & 575473.37 & 575880.27 & -406.90 & 1.48 & 388439.67 & 388714.32 & -274.65 \\
\hline 72 & Hotel and lodging services & 95509.66 & 95535.06 & -25.40 & 1.50 & 63736.84 & 63753.79 & -16.95 \\
\hline 73 & Business services & 172884.08 & 172927.28 & -43.20 & 1.53 & 113181.07 & 113209.35 & -28.28 \\
\hline 74 & Eating and drinking places & 181197.35 & 181202.25 & -4.90 & 1.34 & 135211.81 & 135215.47 & -3.66 \\
\hline 75 & Automobile repair services & 107780.05 & 107799.55 & -19.50 & 1.39 & 77612.19 & 77626.23 & -14.04 \\
\hline 76 & Amusements & 59774.54 & 59786.74 & -12.20 & 1.42 & 42097.71 & 42106.30 & -8.59 \\
\hline 77 & Health, education, and social services & 740963.98 & 741166.88 & -202.90 & 1.53 & 483594.82 & 483727.24 & -132.42 \\
\hline 78 & Federal government enterprise & 11354.57 & 11361.37 & -6.80 & 1.34 & 8484.96 & 8490.04 & -5.08 \\
\hline
\end{tabular}


Table A.5. (contd)

\begin{tabular}{|c|c|c|c|c|c|c|c|c|}
\hline \multirow[b]{2}{*}{ No. } & \multirow[b]{2}{*}{ Industry description } & \multirow[b]{2}{*}{ Base } & \multirow[b]{2}{*}{ CCAP } & \multirow[b]{2}{*}{ Diff } & \multirow[b]{2}{*}{ Deflator } & \multicolumn{3}{|c|}{ Deflated FD, 2000} \\
\hline & & & & & & Base & CCAP & Diff \\
\hline 79 & State and local govemment enterprise & 19623.23 & 19626.13 & -2.90 & 1.48 & 13302.98 & 13304.95 & -1.97 \\
\hline 80 & Noncomparable imports & -41844.00 & -41860.70 & 16.70 & 0.00 & 0.00 & 0.00 & 0.00 \\
\hline 81 & Scrap & -18255.30 & -18255.30 & 0.00 & 0.00 & 0.00 & 0.00 & 0.00 \\
\hline 82 & Govemment industry & 567003.99 & 567003.99 & 0.00 & 1.49 & 380974.26 & 380974.26 & 0.00 \\
\hline 83 & Rest of the world industry & 0.20 & 0.20 & 0.00 & 0.00 & 0.00 & 0.00 & 0.00 \\
\hline 84 & Household industry & 0.00 & 0.00 & 0.00 & 1.10 & 0.00 & 0.00 & 0.00 \\
\hline 85 & Inventory valuation adjustment & 0.00 & 0.00 & 0.00 & 0.00 & 0.00 & 0.00 & 0.00 \\
\hline & TOTALS & 6253970 & 6254162.8 & -192.8 & & 4997233.6 & 4996347.3 & 886.3199 \\
\hline
\end{tabular}




\section{Distribution}

No. of

Copies

Offsite

2 DOE/Office of Scientific and Technical Information (OSTD)

20 P. Podolak

U.S. Department of Energy

Office of Economic Analysis and

Competition

Mail Stop PO-61

Washington, D.C. 20585

B. Card

U.S. Department of Energy

Office of Planning and Assessment

Mail Stop EE-70

Washingțon, D.C. 20585

E. Petersen

U.S. Department of Energy

Office of Planning and Assessment

Mail Stop EE-70

Washington, D.C. 20585
No. of

Copies

Onsite

32 Pacific Northwest Laboratory

D. M. Anderson

W. B. Ashton

D. B. Belzer

A. K. Nicholls

J. M. Roop (25)

R. W. Schultz

M. J. Scott

M. G. Woodruff 
